\title{
Horace R. Blank and the Origin of Rock Doughnuts
}

TWIDALE, R. ${ }^{1}$

${ }^{1}$ Department of Geology and Geophysics, School of Physical and Earth Sciences, University of Adelaide, Adelaide, South Australia.

https://doi.org/10.17979/cadlaxe.2018.40.0.4919

enviado $1 / 1 / 2018$ aceptado $12 / 12 / 2018$

\begin{abstract}
Rock doughnuts are annular rims developed around rock basins that intermittently carry pools of water. They are developed in granitic rocks, and in arenaceous and calcareous sediments and in coastal as wells as interior settings. Rock levees are found adjacent to gutters but are of a similar nature and origin. Both doughnuts and levees can be attributed to the development of protective coatings or veneers by biota, and of silica, iron oxides, and carbonates by overflowing pool waters. Contrasts in drainage from regolithic covers, weathering at sheltered interfaces and variations in runoff can also be cited at causative factors and situations.
\end{abstract}





\section{INTRODUCTION}

Rock doughnuts are annular rims situated around rock basins that for varying periods are occupied by pools of water (fig. 1). The term was introduced by Horace Blank (1951) who had noted examples of the landform on granite hills in central Texas, and elsewhere in the United States (see Thornbury, 1954: 70). Blank (1898-1984) was at the time a Professor of Geology in the then Agricultural and Mechanical College of Texas, the institution that has evolved into the Texas A. and M. University (Popp 1987). Though primarily a mineralogist, his geological interests were wide ranging and included landscape, for his publications include papers on a landslide, incised meanders, and granite weathering, as well as a pioneering investigation of rock doughnuts. Blank was imaginative in his analysis of the forms, and his investigative method was exemplary, for he proposed various possible explanations of the features he had observed and then considered and tested each against his field evidence.

\section{ROCK DOUGHNUTS}

Rock doughnuts vary in size and detailed morphology. There are exceptions, but most are less than $1.5 \mathrm{~m}$ diameter. Some are relatively smooth, others rough (figs 1, 2 and 3). They are found on planate surfaces and on slight inclines. Some are complete, others imperfect and horseshoe-shaped (fig. $3 a)$, though whether they were formed that way or breached after formation is not clear: the fine example of a doughnut located on Enchanted Rock (fig. 1a) appears to be in process of conversion to a horseshoe with overflow concentrated on one lower sector of the rim. Some rock doughnuts developed on the upper shoulder of slopes at the eastern end of Hyden Rock, in the southwest of the Yilgarn Craton of Western Australia of are markedly asymmetrical and enclose basins that are unusually small in relation to the breadth of the surrounding rims (fig. 3b), but most doughnuts are narrower than basin diameter, and stand only a few centimetres higher than the adjacent slopes. All the forms described by Blank are granitic, but examples have been noted also in migmatite, sandstone, silcrete, and calcarenitic limestone. They are found on coasts as well as at interior sites (Twidale 1980, 2017; Twidale and Campbell 1998 at p.1390).

The small size of rock doughnuts distinguishes them from, for instance, the gigantic sandstone cusps described from Utah, in the western United States, which are up to $70 \mathrm{~m}$ high, with crestal depressions and that are structural in origin, having developed on clastic pipes injected in to the host rock (Netoff and Shroba 2001). Similarly, the large basins with jagged rims associated with the Moeraki and Katiki concretionary boulders developed and preserved on the southern coast of South Island, New Zealand (e.g. Brunsden 1969; Boles et al. 1985) are altogether larger than the forms discussed here. Some coastal rock doughnuts also appear to grade into cones with crestal basins and into fonts (the benetiers of Coude Gaussen 1979; Twidale and Campbell 1998) as result of the abrasion by waves of the flanks of the cones (fig. 1e).

\section{BLANK'S WORKING HYPOTHESES}

As Blank realised, rock doughnuts can be explained in various ways. First, he considered, but almost immediately rejected, the possibility that the annular rims were based 
in zones of granite different in composition and texture from the main body of the rock, and more resistant on that account. $\mathrm{He}$ examined the rock in which doughnuts are shaped and could detect no difference from the main mass of country rock (see also Lister 1973.159). And it is indeed difficult to find a primary petrological or lithological structure that would cause rims of rock to become upstanding, either independently or coincidentally around pools of water. Large scale circular and arcuate crustal structures have long been recognised (e.g. Richter and Kaminine 1956; Saul 1978; O'Driscoll and Campbell 1997), arcuate joints are not uncommon in granitic rocks, and concentric mineral bands occur within concentrically fractured igneous rocks as displayed in roadside cuttings (fig. 4), but no horizontal or near horizontal ring-shaped structures have been recorded with distinctive mineral composition or textures and at a scale and distribution appropriate to the range of rock doughnuts.

Second, Blank found one site where an isolated upstanding knob or 'island' of granite had been created by the development of deep gutters on either side, and he speculated whether the knob could be converted to a doughnut assemblage by the preferential weathering and erosion of the crest. $\mathrm{He}$ conceded that scouring of the crest of the knob was unlikely (for instance through his suggested development of an 'exfoliation spall') but in any event the suggestion finds support neither in theory nor in the field, for crests shed water, the great geomorphological destroyer, and so tend to persist (see e.g. Bliss Knopf 1924: 637-638, and 667; Crickmay 1976).

Third, and at the suggestion of Armstrong Price, Blank considered the possible role of case hardening similar to that invoked by Anderson (1931), White (1944), and others in their studies of granite forms, including rock basins, in other parts of the United States. He surmised that salts in solution could be precipitated either within the basins when the pools dried out, or when they overflowed, but found no evidence of such surficial toughening Like the present author, Blank (1951, at p. 825) lacked sophisticated sampling tools, and was reluctant to scar and mar the landforms. It was not possible to identify deeper impregnation. Still with the possibility of superficial protection in mind Blank considered the possible role of biota but noted that the annular rims were not consistently host to lichens and mosses that, alive or dead, might have provided a protective coating.

Fourth and finally, Blank considered whether runoff from upslope could agitate the pool waters sufficiently to cause erosion of the pool walls. Even if such abrasion did occur, however, enlargement of the pools would not create but rather undermine and tend to reduce or eliminate any pre-existing or incipient annular rims, though as noted previously, overflow could explain breached rims that occur on the downslope margin of doughnuts situated on inclined surfaces.

\section{POOLS, AND GNAMMAS OR WEATH- ER PITS}

\section{Initiation of rock basins and significance of pools}

Blank emphasised that rock doughnuts are 'unquestionably connected' with rock basins (the 'weather pits of Matthes 1930, the gnammas' of Australian workers e.g. Twidale and Corbin 1963; Bayly 1999) and 
the pools of water from time to time accumulated there (Blank 1951, p. 825). Rock basins have formed wherever and for whatever reason water has accumulated. Fractures are favoured. Also, the country rock varies in mineralogy and texture at the site scale. For instance, Ferris et al. (1998) noted that granite exposed in Little Wudinna Hill, located some $10 \mathrm{~km}$ northeast of the town of Wudinna, on north western Eyre Peninsula, includes blebs or pods of plagioclase, which is more susceptible to chemical weathering than other contained minerals and thus constitute potential sites for basin development (see also e.g. Bourne and Twidale 2002, p. 95). However, in most instances it is difficult to demonstrate initiation in this manner, for where composition has played a part in initiating weathering and erosion the evidence is likely been eliminated. In any event basins and pools are a common feature of granite surfaces, but, as Blank pointed out (1951, p. 825), there are far more basins and pools than there are rock doughnuts, implying that other factors have intervened.

\section{Protective veneers.}

Blank linked rock doughnuts to the linear rims he found bordering fractures but conceded that this simply transferred the problem to the origin of the rims, the solution of which also escaped him. Raised rims, or 'rock levees,' were noted bordering gutters or shallow minor drainage lines on Domboshawa, a majestic bornhardt locate located near Harare in northern Zimbabwe (Scott 1967) and examples have been noted elsewhere (figs 5a and b). The study of these forms has provided important clues as to the origin of rock doughnuts.
Blank dismissed the possibility of the annular rims being due to protective agencies but elsewhere the field evidence is undeniable. Two types veneer, organic and mineral, have been noted. Even before Blank undertook his investigations, Fry (1926, 1927) had demonstrated that such organisms could extract and concentrate minerals from rocks, and later work has confirmed that original finding and Scott (1967) attributed rock levees (see below) to protection by lichens, mosses and cyanobacteria (also Russ et al. 1996). Still later, observations showed that cyanobacteria can have a protective function for they have caused inversion, converting erstwhile drainage channels to ribs (Twidale and Bourne 2003), and lichens have produced a thin insoluble and hence protective veneer of oxalates on former limestone slopes (Russ et al. 1996). However, and as is frequently the case, citing the possible impacts of micro-organisms introduces possible confusion of cause and effect. In the instance under consideration, have organisms generated the rims or have they colonised pre-existing favourable ecological niches? For instance, are the annular rims from northern Zimbabwe (fig. 6a) protected by a coating of cyanobacteria or are they convenient hosts for the organisms?

That runoff in gutters and overflowing pools influence the formation of rock doughnuts via salts contained in overflowing waters is suggested by the formation of double rims that presumably reflect common levels or stands of pool waters (fig. 7). Incipient rock doughnuts have been noted in sedimentary terrains with sandstone boulders buried and acquiring a ferruginous coat being differentially weathering to produce an upstanding rim around a weathered depression (fig 8). Similar examples have 
developed on calcrete (caliche) blocks with reprecipitated calcium carbonate protecting the rims of pans, and also of dolines. The iron mineral coating pools and rock doughnuts in in granite country is most commonly haematite/goethite (figs. 8 and 1b). In southern South Australia and the southwest of Western Australia the availability of ironrich minerals in run-off and ground waters is accounted for by the recycling after the dissection and break down of the lateritic carapace that was extensively developed in the regions during the later Mesozoic (e.g. Jutson 1934; Playford 1954; Stephens 1971; Twidale 1983; Twidale and Bourne 1998). Just as carbonates are plentiful in karstic settings, so salts of iron have been widely available in run-off and groundwaters in the regions named.

Several rock doughnuts encircling pans on Hyden Rock and bordering gutters on McDermid Rock and Domboshawa appear to be indurated by siliceous minerals (fig 9) and Lister (1973, p.160) prophetically introduced the possibility of soluble silica being deposited by overflowing waters from pools and runoff on the rock marginal to pools and in such a way as to 'harden and protect the underlying rock and leave the surface between gutters to be scoured and lowered.' She attempted to ascertain whether the silica a surficial coating or reflected impregnation by examining rock from rock levees in thin section with a basic petrological microscope. She found no evidence of compositional buttressing and no opaline coatings on crystals. Using the same technology, the present author could but agree with this conclusion. Whitlow and Shakesby (1988) however, using a scanning electron microscope found thin silicon coatings, the silica, presumably derived from the water flow in the gutters.
Given the high average silica content of natural streams and groundwaters (e.g. Davis 1964) and despite the limited catchments of some gutters with bordering rims, this hypothesis is feasible and finds support in the extension of a resistant coating over some valley floors (fig. 10).

\section{Contrasts in drainage.}

An alternative or complementary explanation for rock levees was proposed by Twidale (1993), and later extended to rock doughnuts that occur on the Talia coast of Eyre Peninsula (Twidale and Campbell 1998). Rock doughnuts would be explained if the adjacent areas were preferentially lowered, leaving the annular rings in positive relief. Given a slope carrying a thin regolith and drained by a shallow gutter, the bedrock surface beneath the moist regolith was etched and lowered. But when the gutter was dry, regolith moisture could seep into the void so that etching at the base of the regolith was slower than in adjacent moister areas. The same mechanism operating in the context of a pool rather than a linear gutter or fracture (figs 11 and 12a). Coastal and other saline environments where the 'regolith' consists of sand or shell grit that retains seawater are especially favourable for rock doughnut formation in the context of contrasted local drainage. The mechanism is most effective where the gutters or pools are dry, so that the formation of rims is favoured by regimes with seasonal or episodic rains and dry periods, or coastal areas subject to marked tidal ranges. Some coastal environments are additionally favoured by summer drought and high temperatures that cause pools and beaches whether of sand or shell grit located near the near upper tide limit to 
evaporate. For these reasons doughnut complexes are common at coastal sites such as Talia on the west coast of Eyre Peninsula (see also Fairbridge 1947-8; Hills1971).

Most doughnuts are epigene in origin, but a possible exception is exposed on a granite platform located some $14 \mathrm{~km}$ north of Minnipa, on north western Eyre Peninsula. It was cleared from beneath a thin (15-20 $\mathrm{cm})$ soil cover in the $1950 \mathrm{~s}$, revealing several shallow saucer-shaped depressions. They could have served as foci for soil drainage and thus retarded weathering of the annular zones formed around them, thus presaging a series of rock doughnuts (fig. 12b).

Contrasts in marginal and interior rock drainage on some of the exposed granite platforms developed on many of the scattered granite outcrops of the South East of South Australia have generated broad incipient rims or rock doughnuts, around central shallow depressions with debris and in some instances remnants of the blocks and boulders that formerly stood there. Richardson Rocks for example, located some $17 \mathrm{~km}$ south of Coonalpyn, in the South East District of South Australia, is a group of large granite boulders several of which have been partly or wholly planed off by a regolith charged with shallow groundwaters rich in carbonic acid. The platforms produced stand a few tens of centimetres higher than the plain (fig.13a). The margins are well drained but in the central areas there is less runoff with the result that mineral and vegetable detritus remain, remains. It retains moisture charged with chemicals and biota. The rock surface beneath is rotted and lowered. This has produced platforms are slightly basined, inviting further alteration in the depressed areas by water and the organisms that moisture attracts (Twidale and Bourne 1976). However, in many places such platform remnants retain a boulder or block standing on pedestals in the shape of rimmed saucer like depressions (see fig. 13b and Twidale and Bourne1977, also the 'Umbrella effect').

\section{'Umbrella' effect}

Blocks and boulders act as umbrellas for they not only shield the surfaces on which they stand from the direct effects of rainfall, but also effectively concentrate run off from the upstanding rocks on to the surrounding surfaces in patterns that reflect the plan shapes of the residuals. The concentration of water causes weathering in these local piedmonts to be more rapid, creating depressions around the residuals (see Pugh1956; Clayton 1956; Twidale 1962). This explanation embraces reinforcement insofar as once formed even the slightest depression attracts and holds water that further encourages plant growth, and further weathering. The areas on which stand the residual blocks and boulders become pedestals standing higher than the surrounding slopes (fig. 14a). The interface between pedestal and standing block or boulder remnants is moist. It attracts biota. Both the upper surface of the pedestal and the base of the standing block or boulder are weathered and hollowed out (figs $13 \mathrm{~b}$ and 14b) so that if the blocks were to be eliminated a hollowed pedestal - or rock doughnut would remain (Twidale and Bourne 1977).

In terms of the umbrella hypothesis the blocks or boulders beneath which differential weathering has been noted, logically ought to remain in place for a considerable time. They shed water and sit on firm bases. Yet few vestiges of such blocks and boul- 
ders remain. Fragments of granite remain in some shallow basins with rock doughnuts, but they appear to be few. On the other hand, granite tends to display a bimodal habit, because once some of the mineral assemblage, and notably mica or feldspar, are altered, water penetrates more readily (reinforcement effect) and the rock rapidly crumbles (see e.g. Scrivenor 1931: 136-137; Alexander 1959). Granite takes the form either of solid blocks, boulders, or larger residuals, or it us reduced to aggregates of granular fragments, grus, sand and clay, detritus that is readily washed or blown away.

\section{CONCLUSIONS}

Blank pointed out that the annular rims are far fewer than the basins with which they are coincident, but he considered that they are formed from "some unusual modification or extension of the processes responsible for the pits" (Blank 1951, p. 825). And certainly, rock doughnuts are comparatively rare, though as is frequently the case, the occur in abundance in favourable settings such as the Talia sandstone coast, and more will be recognised once field workers are aware of the existence of the form and they, as they were, 'get their eyes in', or recognise rock doughnuts for what they are. Isolated examples occur in many areas both inland and on the coast. Not all are recorded in the literature. Of the subsequent working hypotheses proposed in explanation of rock doughnuts, the development of resistant veneers marginal to pools has been demonstrated and the formation of depressions with annular rims underneath boulders is noticeable though too many of the sheltering boulders remain in place. Differential drainage may account for many coastal occurrences as well as complementing the structural contrast created by the formation of veneers. The umbrella effect may indicate how rock doughnuts have formed in the past and may develop in the future.

Horace Blank's was a stimulating introduction to the study of rock doughnuts, and by inference rock levees. He was unable to resolve the question of their origin. Indeed, his was a classic scientific study in the Popperian sense (Popper 1973) in that as he himself conceded, he was able to disprove all his competing working hypotheses. He was disappointed in his own efforts. Yet he made useful suggestions as to possible origins and in any case negative results frequently benefit those who follow. Thus, it is appropriate to recall Blank's perceptive pioneering investigation of a landform that continues to pose problems for geomorphologists.

\section{ACKNOWLEDGEMENTS}

Albeit belatedly, the writer thanks the late Linley Lister (1936 - 2016) for a stimulating introduction to Domboshawa, a site that features prominently in this paper. Her father, Lester King, would have been proud of Linley's contributions to her work on various aspects of Zimbabwean landscape evolution. Ric Giardino, of the Texas A. and M. University, encouraging and supported this appreciation of Blank's work.

\section{REFERENCES}

Alexander, F. E. S., Observations on tropical weathering: a study of the movement of iron, aluminium, and silicon in weathering rocks at Singapore. - Quarterly Journal of the Geological Society of London, 1959. 115: 123-142. 
Anderson A.L., Geology and mineral resources of eastern Cassia County, Idaho. Idaho Bureau of Mines and Geology Bulletin, 1931,14, 169 p.

Bayly, I., Rock of Ages. (Nedlands, Tuart House/University of Western Australia Press, 1999). 132 p.

Blank, H.R., "Rock doughnuts", a product of granite weathering. American Journal of Science, 1951, 249, 822-829.

BLISS KNOPF, E., Correlation of residual erosion surfaces in the eastern Appalachians. Geological Society of America Bulletin, 1924, 35, 633-668.

Boles, R., Landis C. A. and Dale P., The Moeraki Boulders. New Zealand Journal of Geology and Geophysics, 1985,16. 158-169.

Bourne, J. A. and Twidale, C. R., Morphology and origin of three bornhardt inselbergs near Lake Johnston, Dundas Shire, Western Australia. Journal of the Royal Society of Western Australia, 2002,85 83-102.

Brunsden D., Mystery of the Moeraki and Katiki boulders. Geographical Magazine, 1969, 41, 839-841.

Clayton R.W., Linear depressions (Bergfussniederungen) in savannah landscapes. Geographical Studies. 1956. 3: 102-126.

Coude-Gaussen, G. Les Serras da Peneda et do Geres. Etude Gémorphologique. (Lisbon, Universidade de Lisboa. Institut National de Investigaçao Científica, Memorias do Centro de Estudós Geograficos, 1981) $254 \mathrm{p}$.

Crickmay C.H., The hypothesis of unequal activity, pp. 103-109 in MELHORN W.N. and FLEMAL R.C. (Editors) Theories of Landform Development. (Binghamton, State University of New York, 1976), $306 \mathrm{p}$.
Davis S. N., Silica in streams and groundwater. American Journal of Science,1964, 262, 870-891.

Fairbridge, R.W., The geology and geomorphology of Point Peron, Western Australia. Journal of the Royal Society of Western Australia, 1947-48, 34, 37-72

Ferris, G.M., Gray, N.D. and Pain, A.M., Reconnaissance granite sampling of the Mesoproterozoic Hiltaba Suite Granite on northern Eyre Peninsula, South Australia for Dimension Stone. 1998, PIRSA, Adelaide, Report Book 97-28 (CD-ROM).

Fry E.J., The mechanical action of corticolous lichens. Annals of Botany, 1926, 40, 397-417.

Fry, E. J., 'The mechanical action of crustaceous lichens on substrata of shale, schist, gneiss, limestone and obsidian'. Annals of Botany, 1927, 41, 437-460.

Hills E.S., A study of cliffy coastal profiles based on examples in Victoria, Australia. Zeitschrift für Geomorphologie, 1971, 15, 137-180.

Jutson J.T., The physiography (geomorphology) of Western Australia. Geological Survey of Western Australia Bulletin, 1934, 95, 366 p.

Lister LA., The micromorphology of granite hills in north-eastern Rhodesia. Geological Society of South Africa Special Publication, 1973, 3, 157-161.

Matthes, F.E., Geologic history of the Yosemite Valley. United States Geological Survey Professional Paper, 1930, 60. 137 p.

Netoff, D.I. and Shroba R.R., Conical sandstone landforms cored with clastic pipes in Glen Canyon National Recreation Area, southeastern Utah. Geomorphology, 2001, 39, 99-110. 
O’Driscoll E.S.T. and Campbell I.B., Mineral deposits related to Australian continental ring and rift structures with some terrestrial and planetary analogues. Global Tectonics and Metallogeny, 1997. 6, 83-101.

Playford P.E., Observations on laterite in Western Australia. Australian Journal of Science, 1954, 17, 11-14.

Popp, R.K., Memorial of Horace R. Blank. August 8, 1898-January 22, 1984, American Mineralogist, 1987, 72, 444-445

Popper, K.R., Conjectures and Refutations. The Growth of Scientific Knowledge. (London, Routledge and Kegan Paul, 1963), $431 \mathrm{p}$.

Pugh, J.C., Fringing pediments and marginal depressions in the inselberg landscape of Nigeria. Transactions and Papers of the Institute of British Geographers, 1956, 22, 15-31.

Richter, G.D. and Kamanine, L.G., Caractéristique comparative morphologique des boucliers de la partie Européenne de URSS, pp. 82-92 in Essais de Géographie. (Moscow, Academie des Sciences de l'URSS, 1956).

Russ J., Palma R.L., Loyd D.H., Boutton T.W. and Coy M.A., Origin of the Whewellite rich rock crust in the Lower Pecos region of southwest Texas and its significance to paleoclimate reconstructions. Quaternary Research, 1996, 46, 27-36.

Saul, J.M., Circular structures of large scale and great age at the Earth's surface. Nature, 1978, 271, 345-349.

Scott, G.D., Studies of the lichen symbiosis. 3. The water relations of lichens on granite kopjes in central Africa. - The Lichenologist, 1967, 3, 368-385.

Scrivenor, J. B., Geology of Malaya. Quarterly Journal of the Geological Society of London, 1913, 69, 343-369.

Stephens, C.G., Laterite and silcrete: a study of the genetic relationships of laterite and silcrete and their companion materials. and their collective significance in the formation of the weathered mantle, soils, relief and drainage of the Australian continent. Geoderma, 1971, 5-52.

Thornbury, W.D. Principles of Geomorphology. (Wiley, New York Wiley, 1954) 618p.

Twidale, C.R., Steepened margins of inselbergs from north-western Eyre Peninsula, South Australia. Zeitschrift für Geomorphologie, 1962, 6, 51-69.

Twidale, C.R., Origin of minor sandstone landforms. Erdkunde, 1980, 34, 219-224.

Twidale, C.R., Australian laterites and silcretes: ages and significance. Revue de Geologie Dynamique et Geographie Physique, 1983, 24, 35-45.

Twidale, C.R., The research frontier and beyond: granitic terrains, pp. 187-223 in J.D. VITEK and J.R. GIARDINO (Editors) Special Issue, Geomorphology: The Research Frontier and Beyond 7(1-3) Proceedings of the 24th Binghamton Symposium in Geomorphology, 25 August 1993. (Amsterdam, Elsevier, 1993. 265 p.

Twidale, C.R., The putative pre-Cenozoic age of Waddikee Rocks, Koongawa, northern Eyre Peninsula, South Australia. Transactions of the Royal Society of South Australia ,2017, 141, 70-82.

Twidale C.R. and Bourne, J.A., The shaping and interpretation of large residual granite boulders. Journal of the Geological Society of Australia, 1976, 23, 371-381.

Twidale, C.R. and Bourne, J.A., Rock doughnuts. Revue de Géomorphologie Dynamique, 1977, 26, 15-28.

Twidale C.R. and Bourne, J.A., Origin and age of bornhardts, southwest Western 
Australia. Australian Journal of Earth Sciences, 1998, 45, 903-914.

Twidale, C.R. and Bourne, J.A., Origin and inversion of fluting in granitic rocks. Australian Journal of Earth Sciences, 2003, 50, 543-552.

Twidale, C.R. and Campbell, E.M., Development of a basin, doughnut, and font assemblage on a sandstone coast, western Eyre Peninsula, South Australia, Journal of Coastal Research,1944, 14, 1385-1394.

Twidale, C.R. and Corbin E.M., Gnammas. Revue de Géomorphologie Dynamique, 1963, 14, 1-20.

White, W.A., Geomorphic effects of indurated veneers on granites in southeastern states. The Journal of Geology, 1944, 52, 333-341.
Whitlow, R. and Shakesby, R.A., Bornhardt micro-geomorphology: form and origin of microvalleys and rimmed gutters, Domboshawa, Zimbabwe. 1988, Zeitschrift für Geomorphologie, 32: 179-194.

\section{CAPTIONS}

1.Rock doughnuts (a) in granite on Enchanted Rock, central Texas (b) on low gneiss dome some $18 \mathrm{~km}$ north of Payne's Find (200km NNE of Perth), Yilgarn Craton, Western Australia (c) in sandstone, southern Drakensberg, Eastern Cape Province, RSA (d) in migmatite, Waddikee Rocks, in the Koongawa district of north western Eyre Peninsula. (e) in sandstone, Talia coast western Eyre Peninsula, between Port Kenny and Elliston.

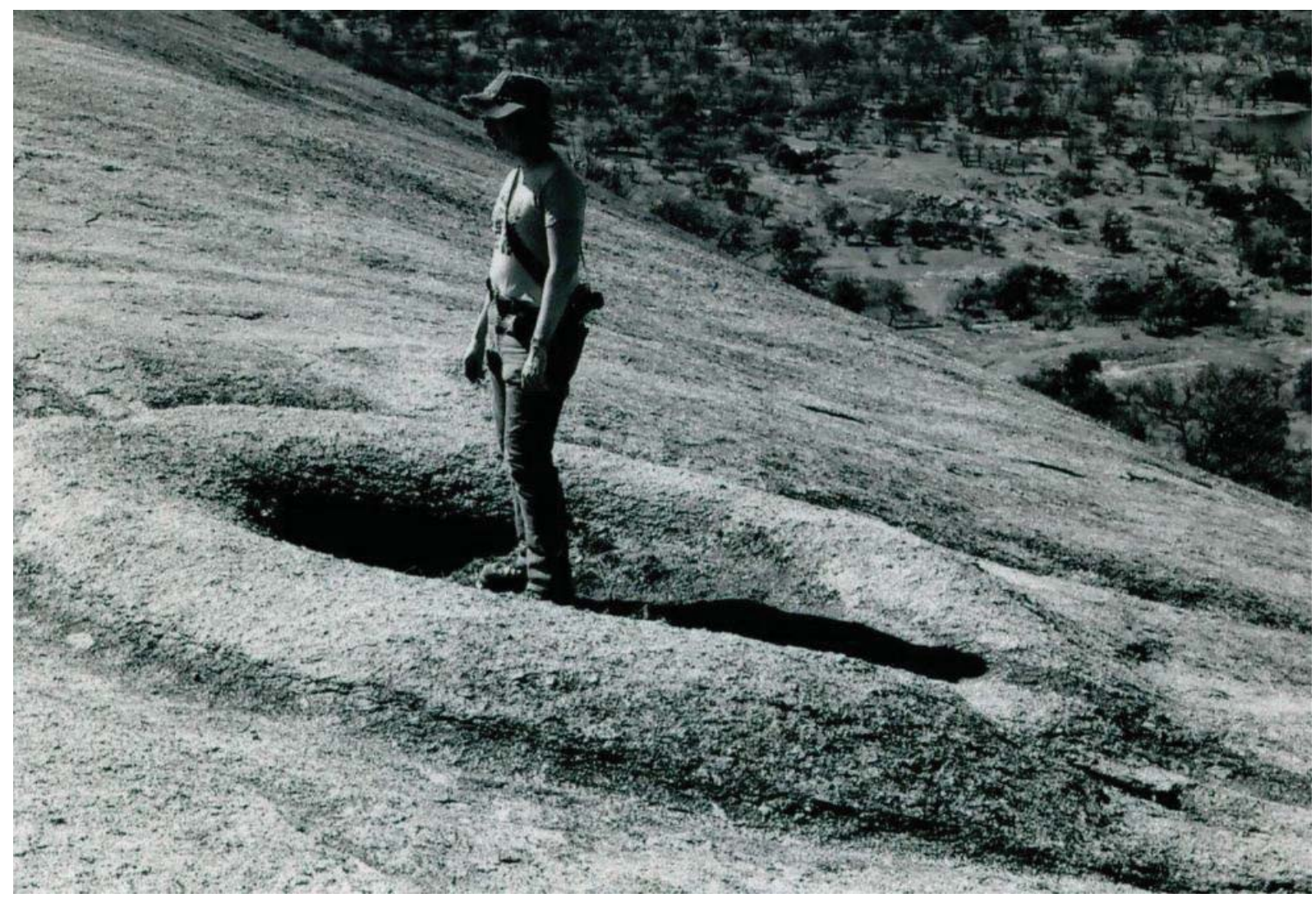

Fig. 1a. 


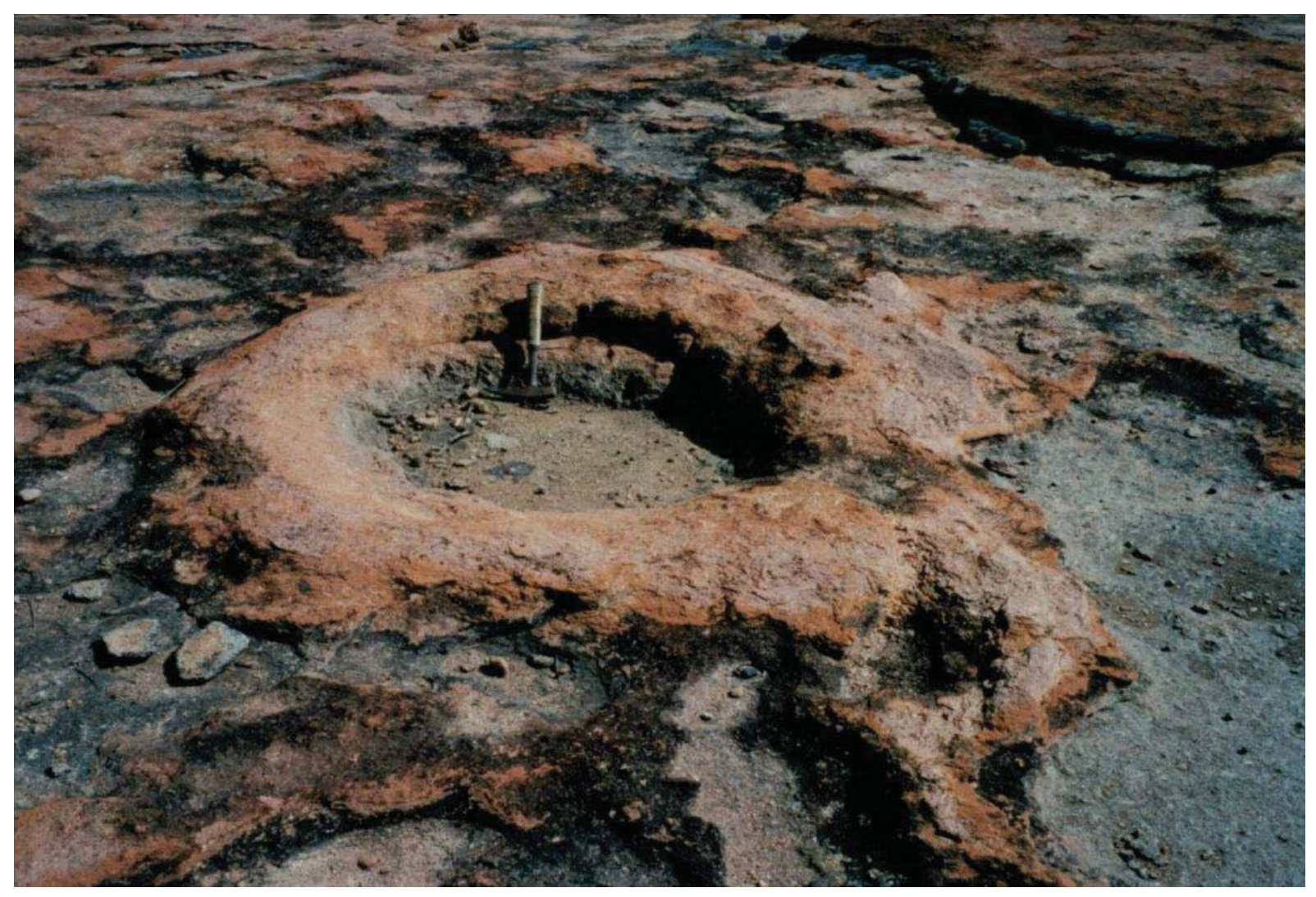

Fig. 1b. 


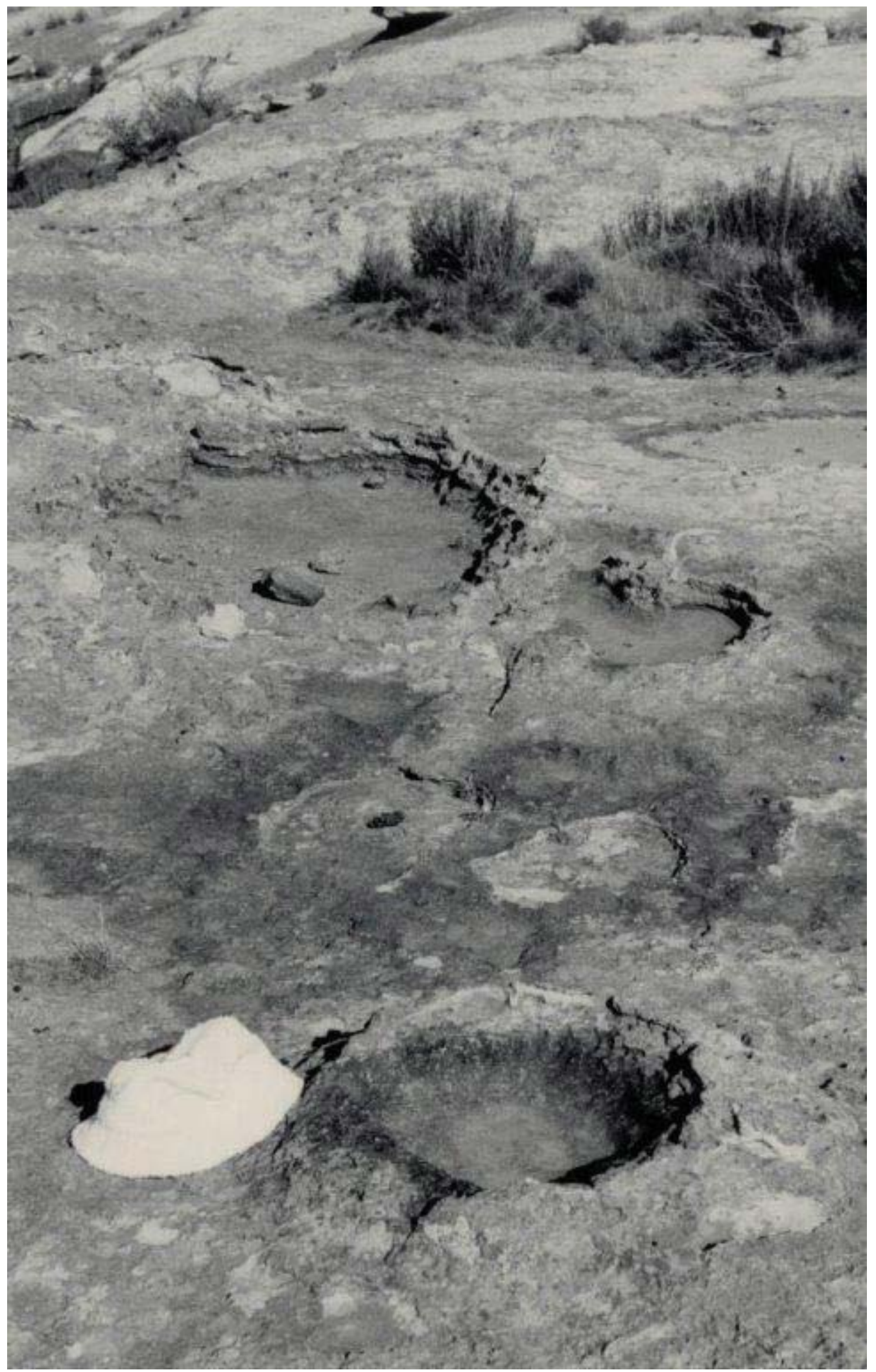

Fig. 1c. 


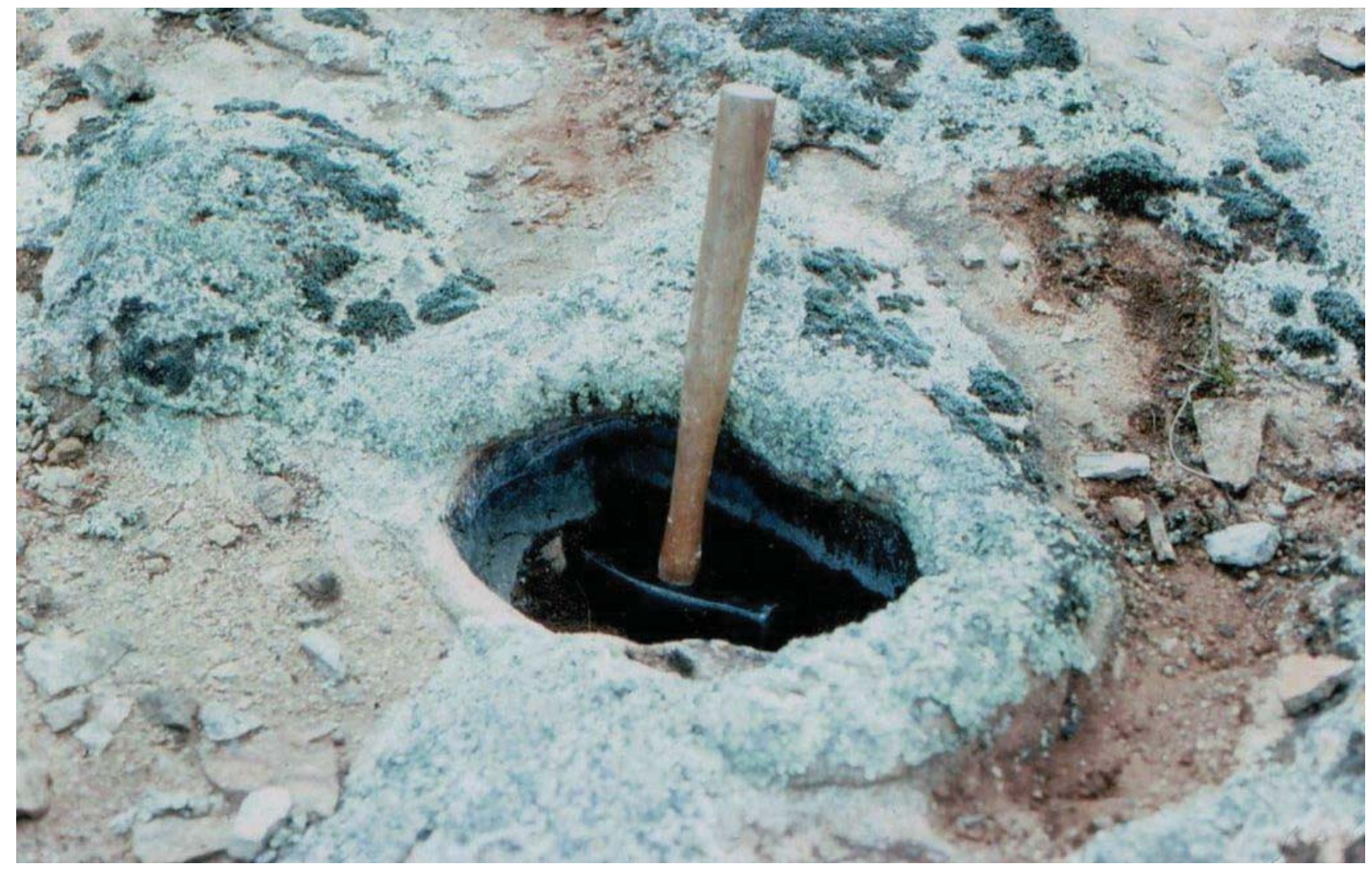

Fig. 1d.

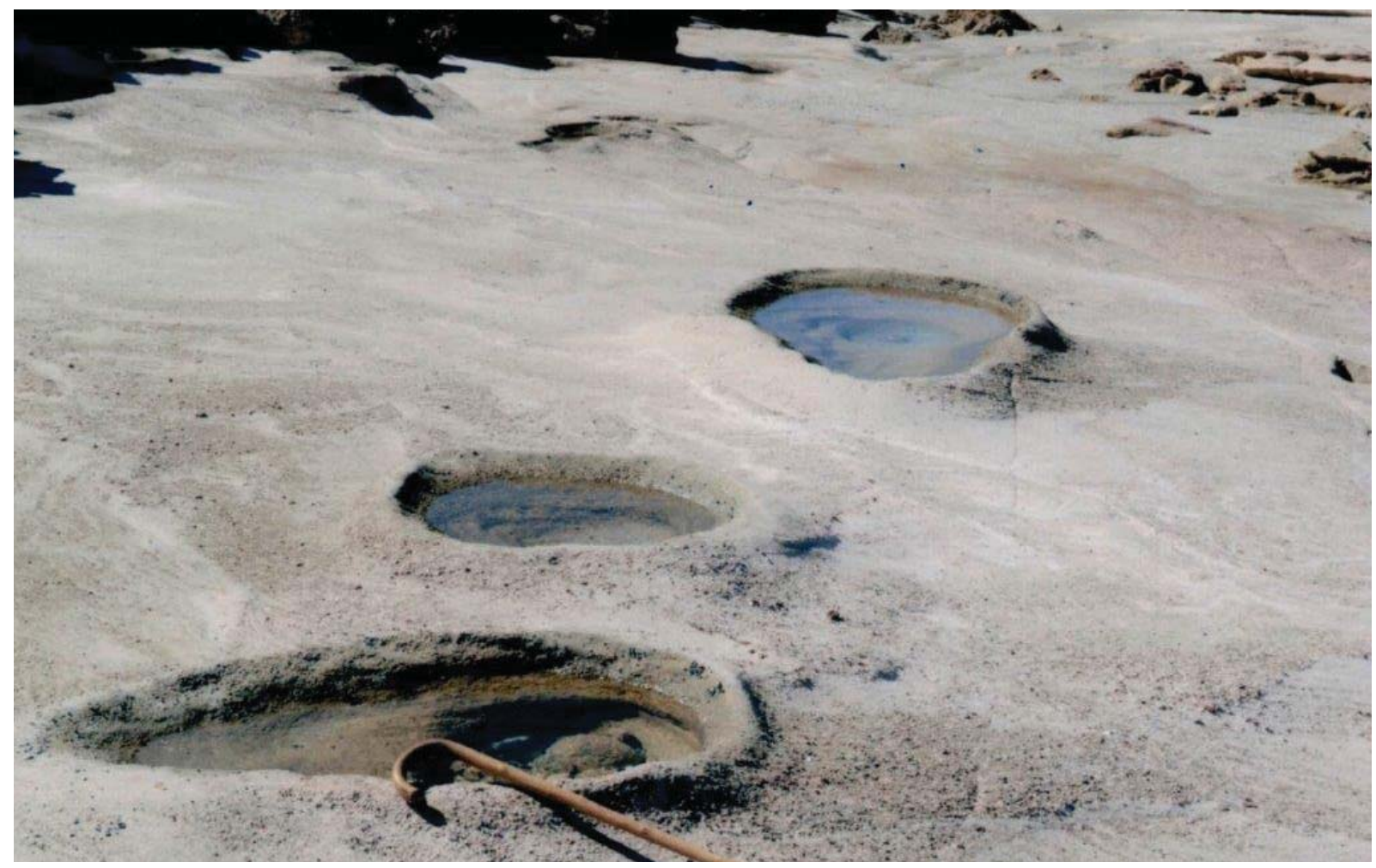

Fig. 1e. 


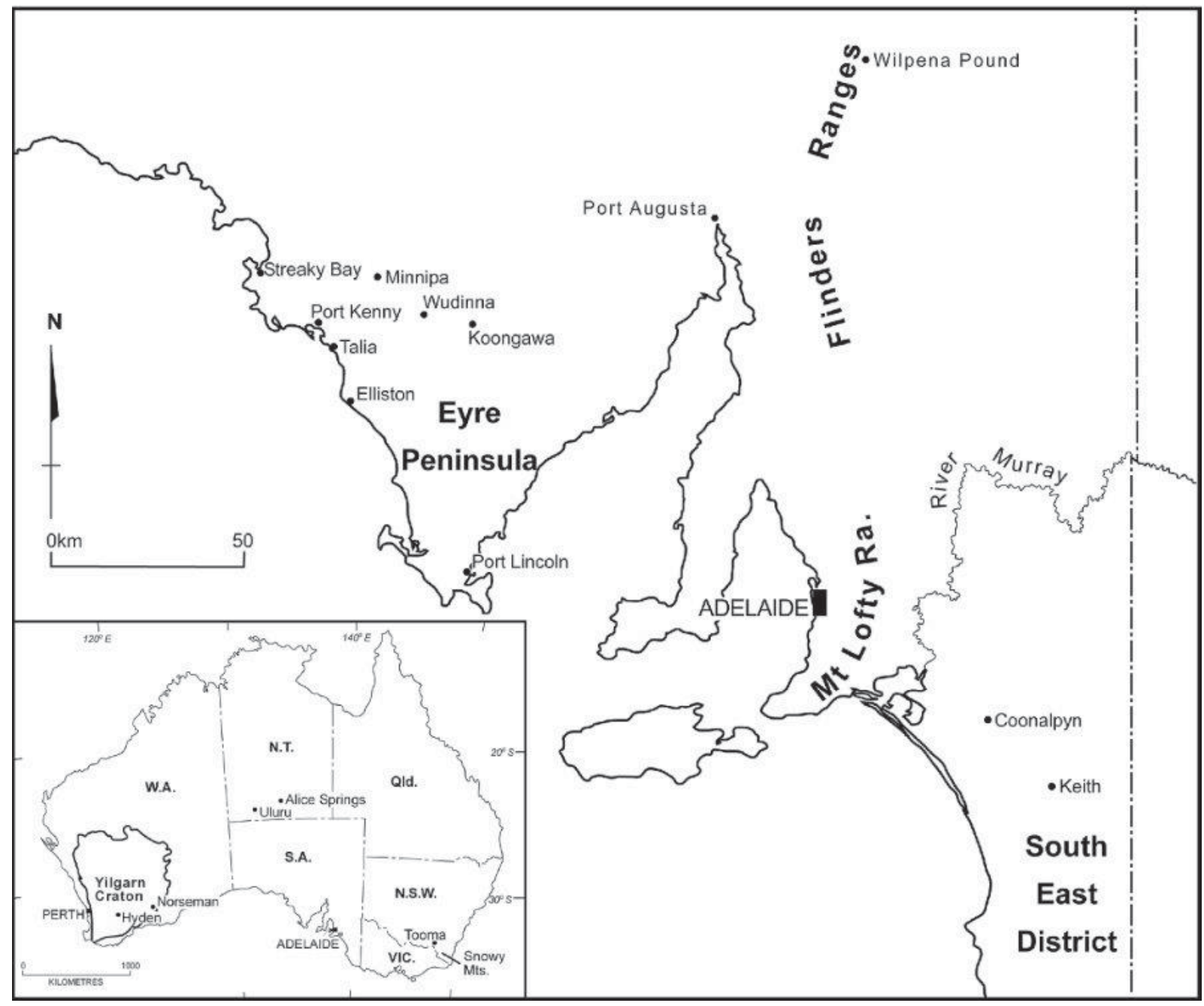

Fig. 2. Location map. 


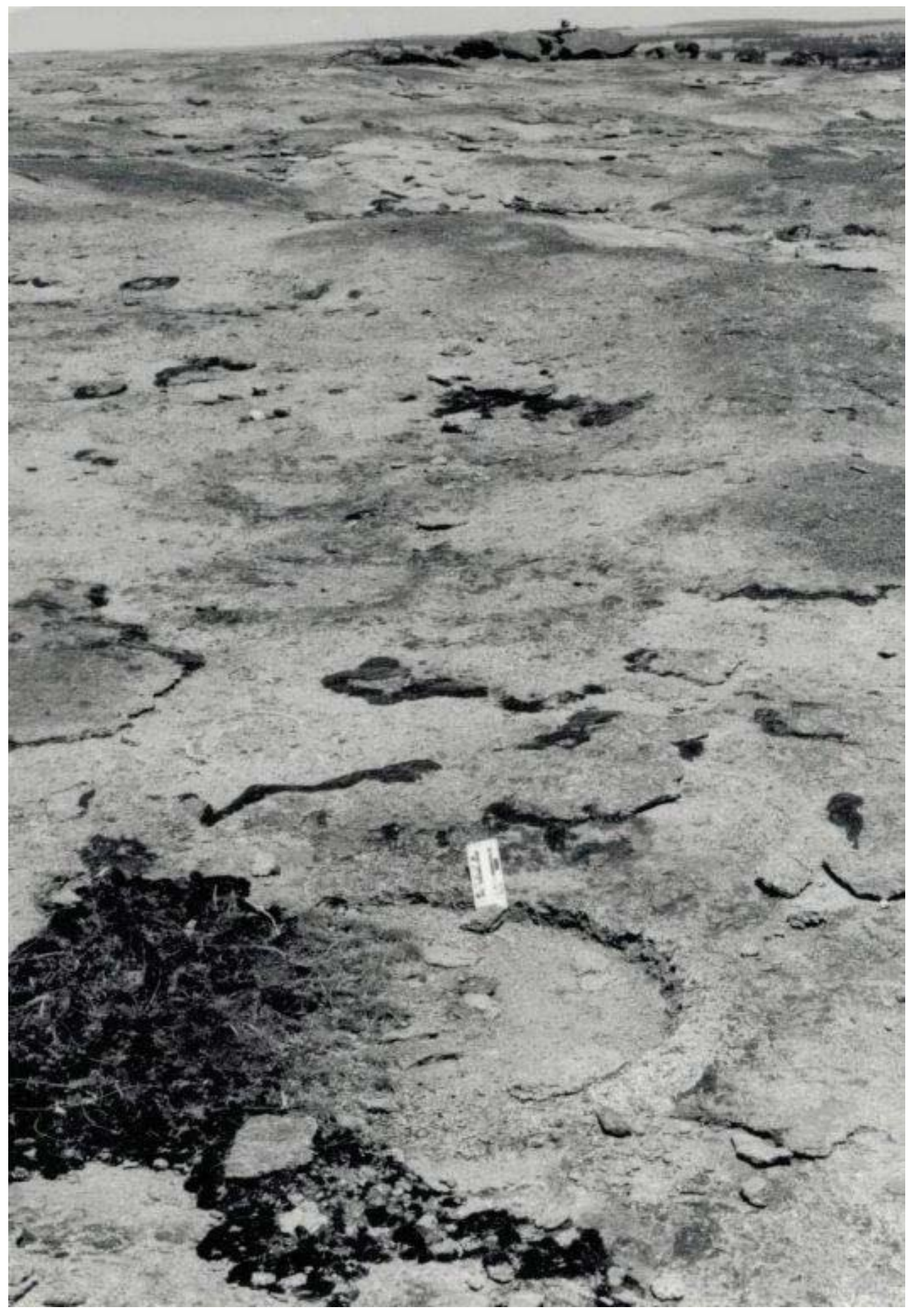

Fig. 3. (a). Incomplete rim around pool, eastern sector of Hyden Rock, near Hyden township, Western Australia (b) Asymmetrical doughnut, one of several developed on the eastern end of Hyden Rock. 


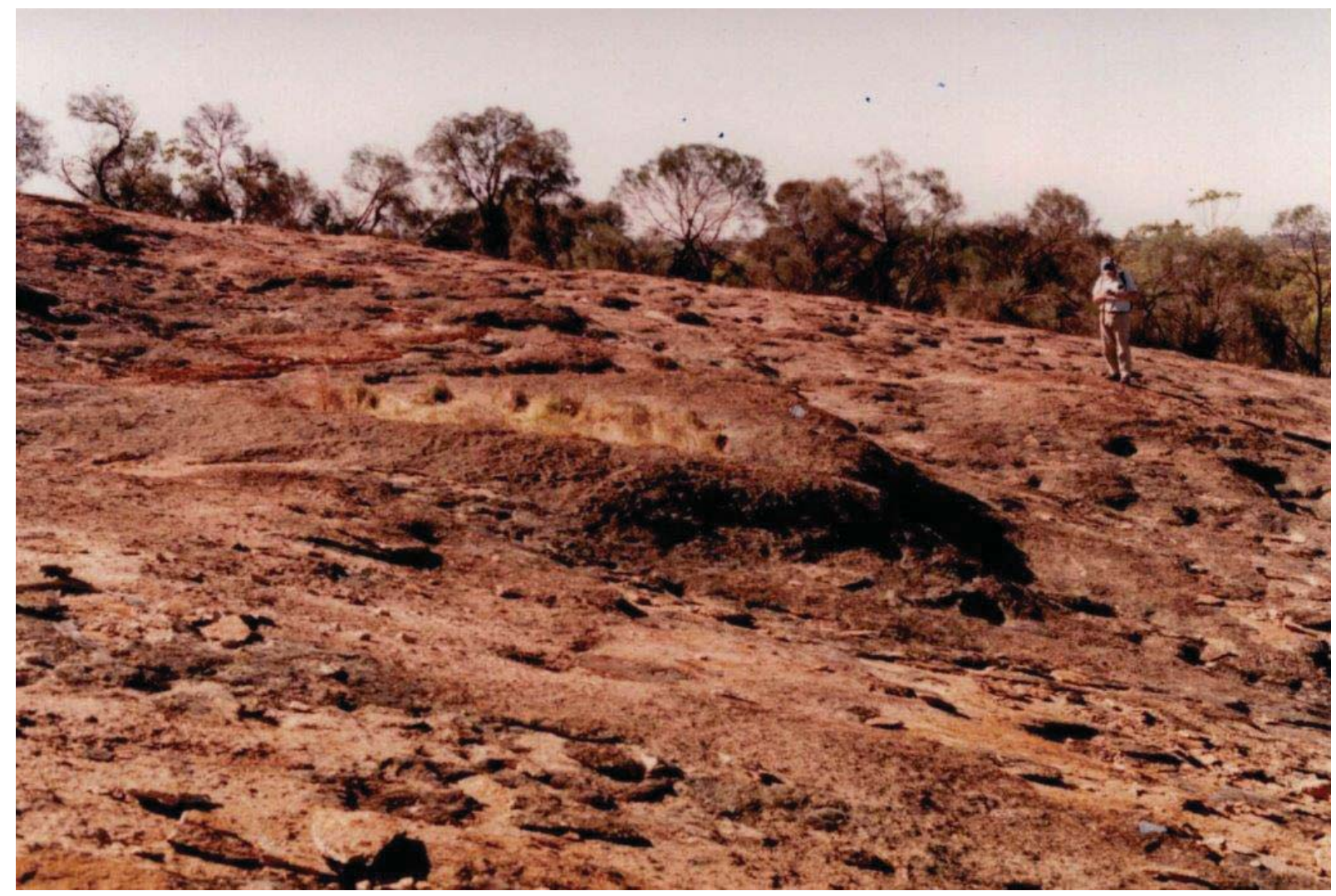

Fig. 3b. 
4. Corestones with concentric plates and concentric mineral (feldspars, ferromagnesians) separation, Tooma Dam, Snowy
Mountains, New South Wales. The rock fragment with parallel mineral zones (b) is located above the head of the boy providing scale in (a).

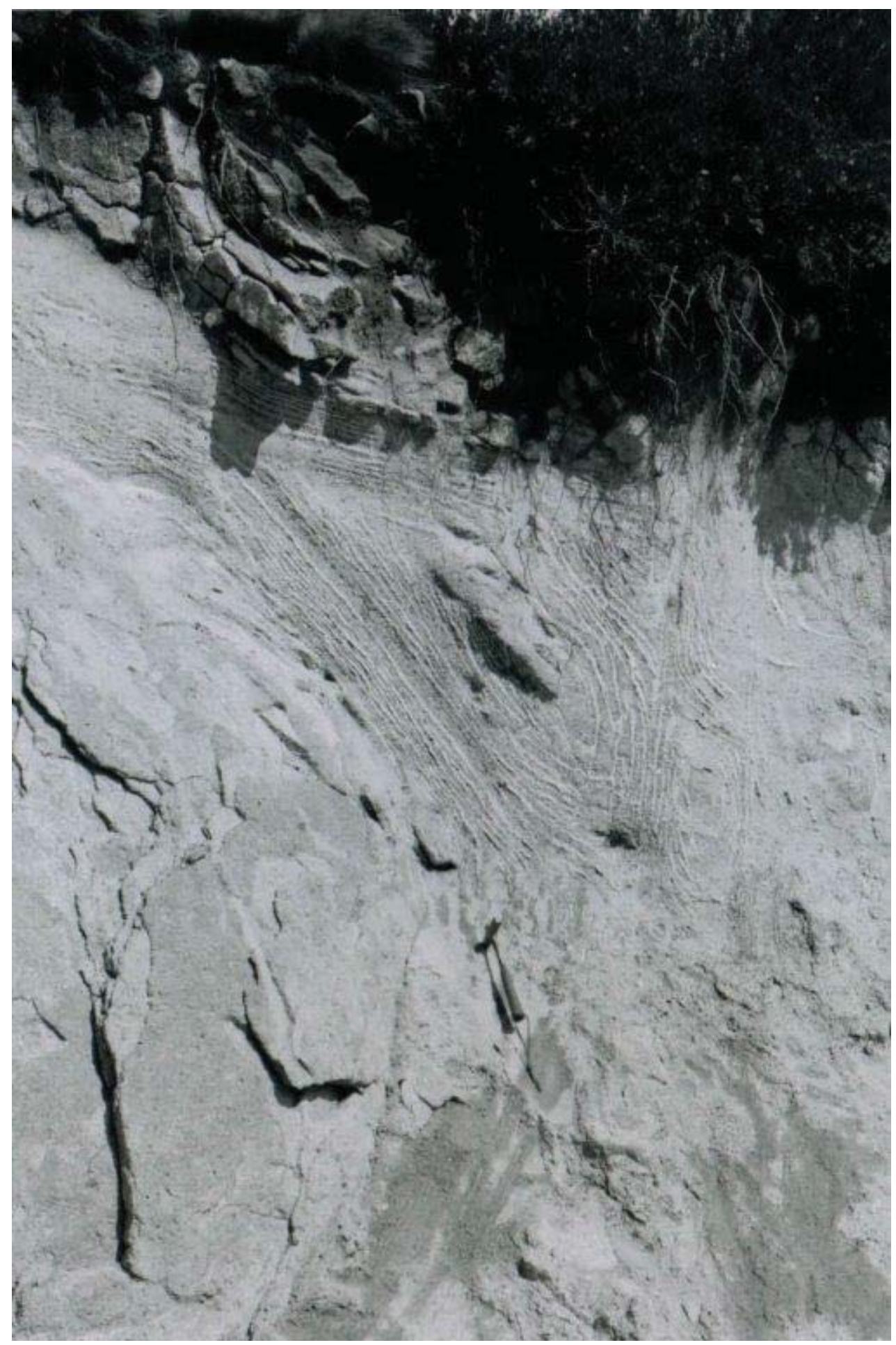

Fig. 4a. 


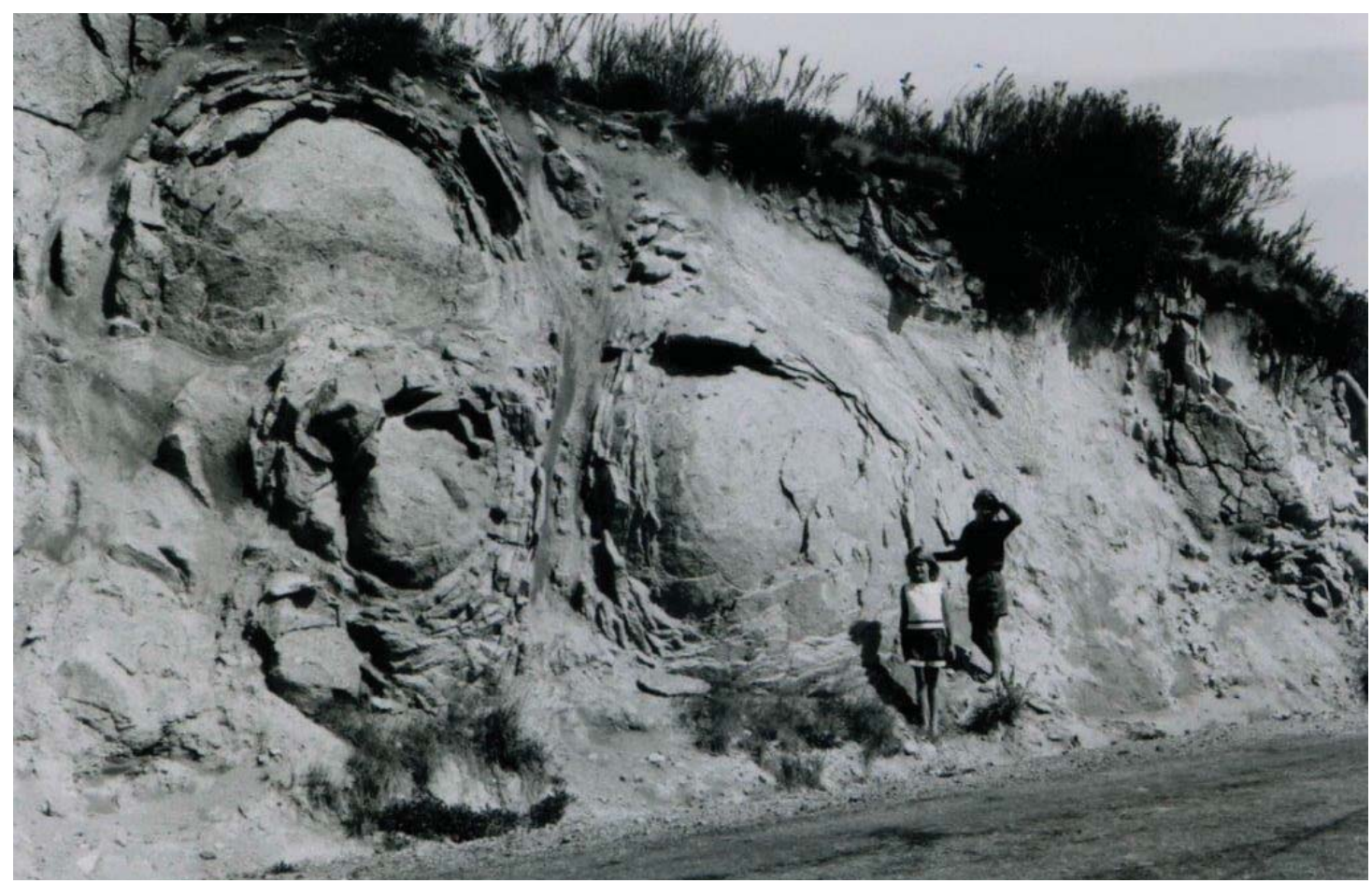

Fig. 4b.

5. Rock levees (a) on Domboshawa, nor- $\quad$ circa $100 \mathrm{~km}$ north east of Norseman, Westhern Zimbabwe, (b) on McDermid Rock tern Australia.

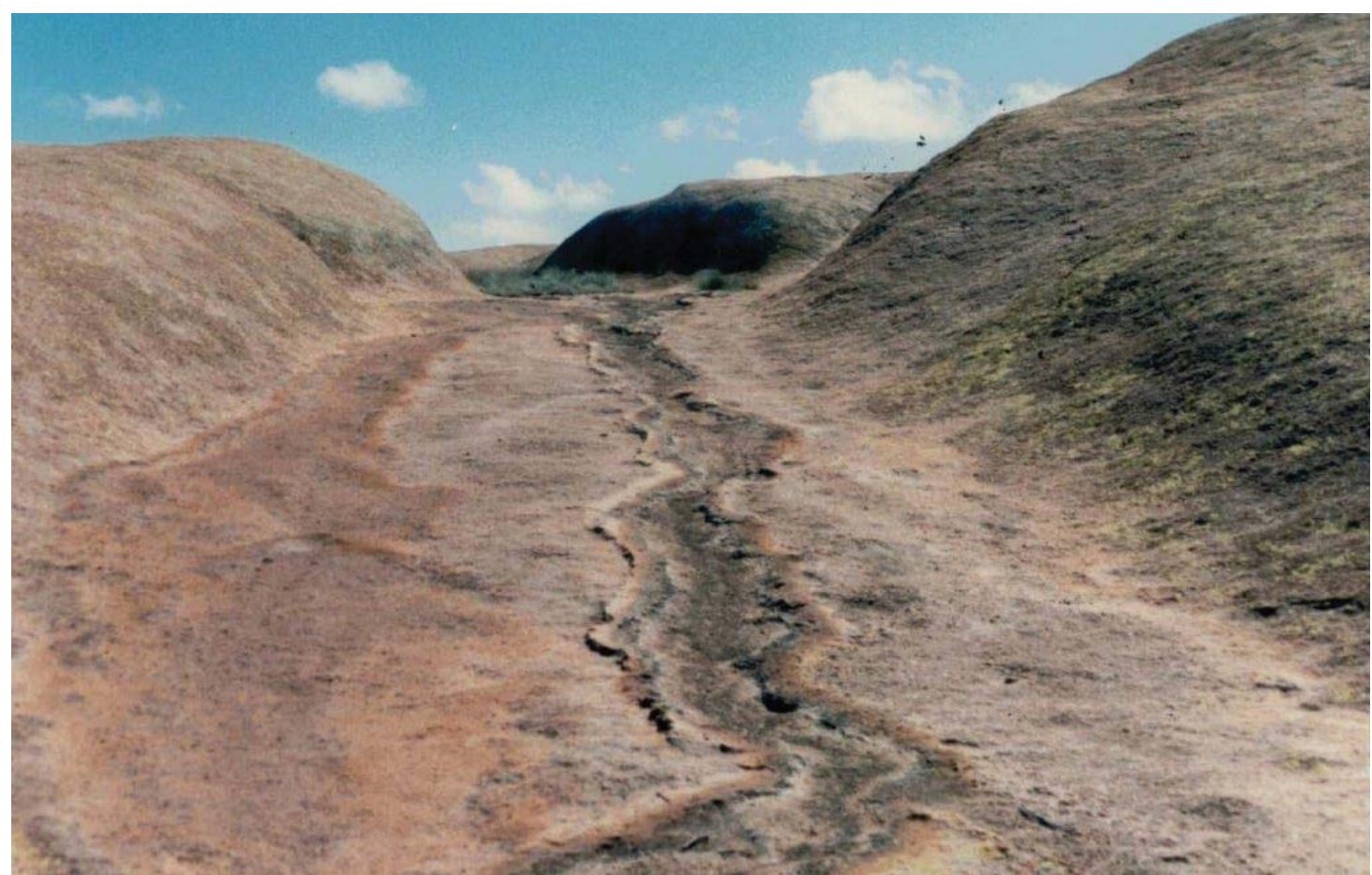

Fig. 5a. 


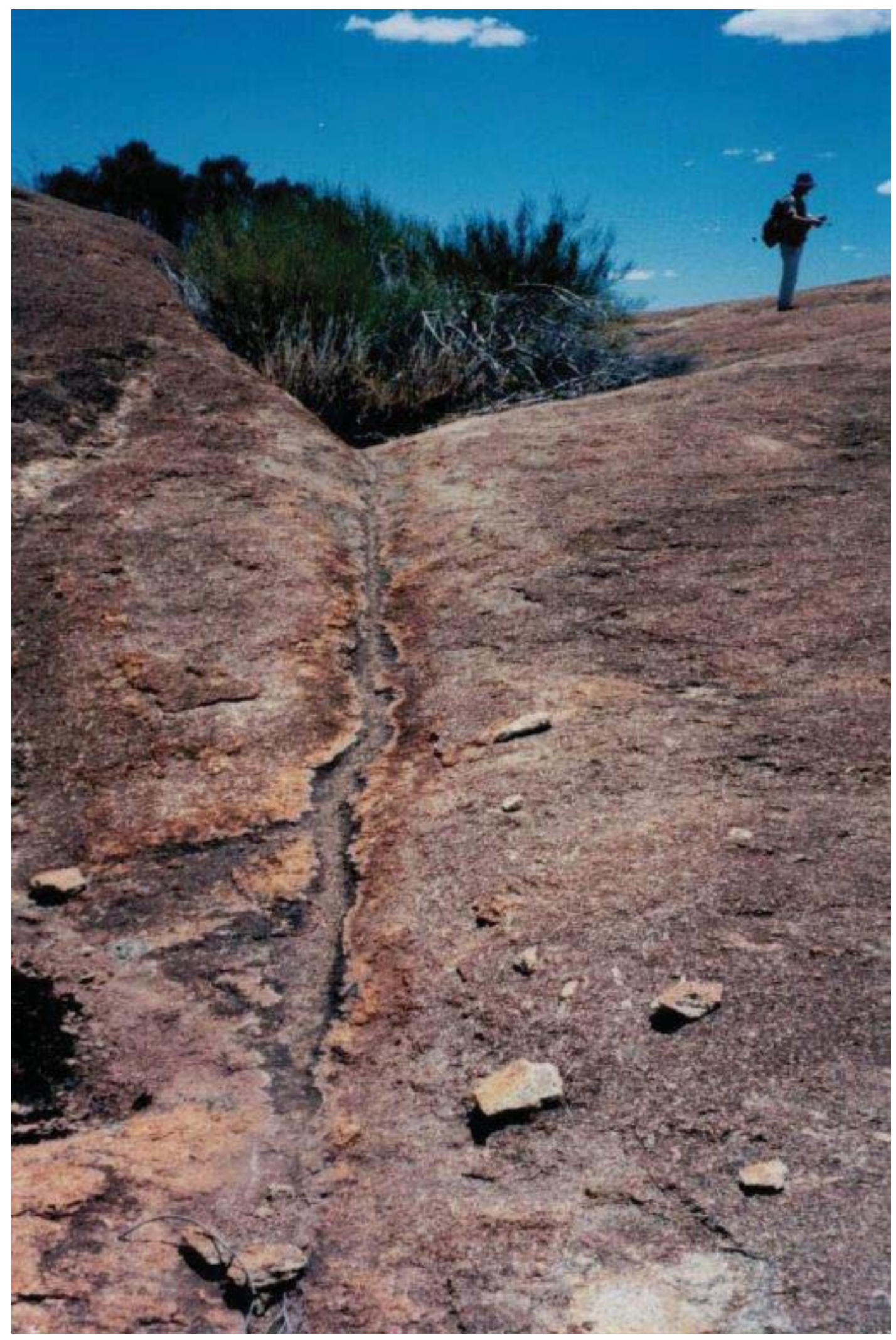

Fig. 5b. 


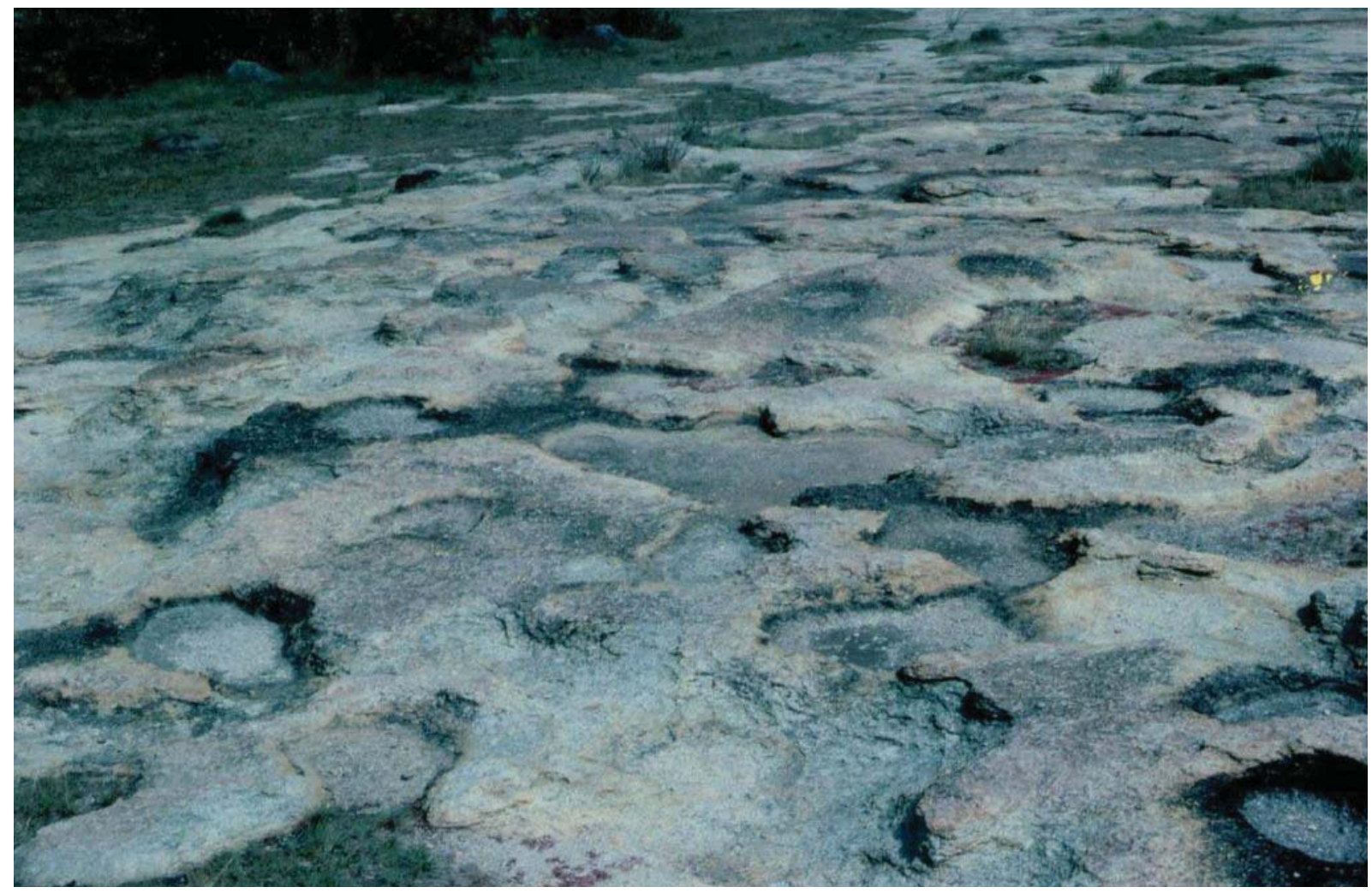

Fig. 6. Granite platform with pans and annular rims coated with cyanobacteria, northern Zimbabwe.

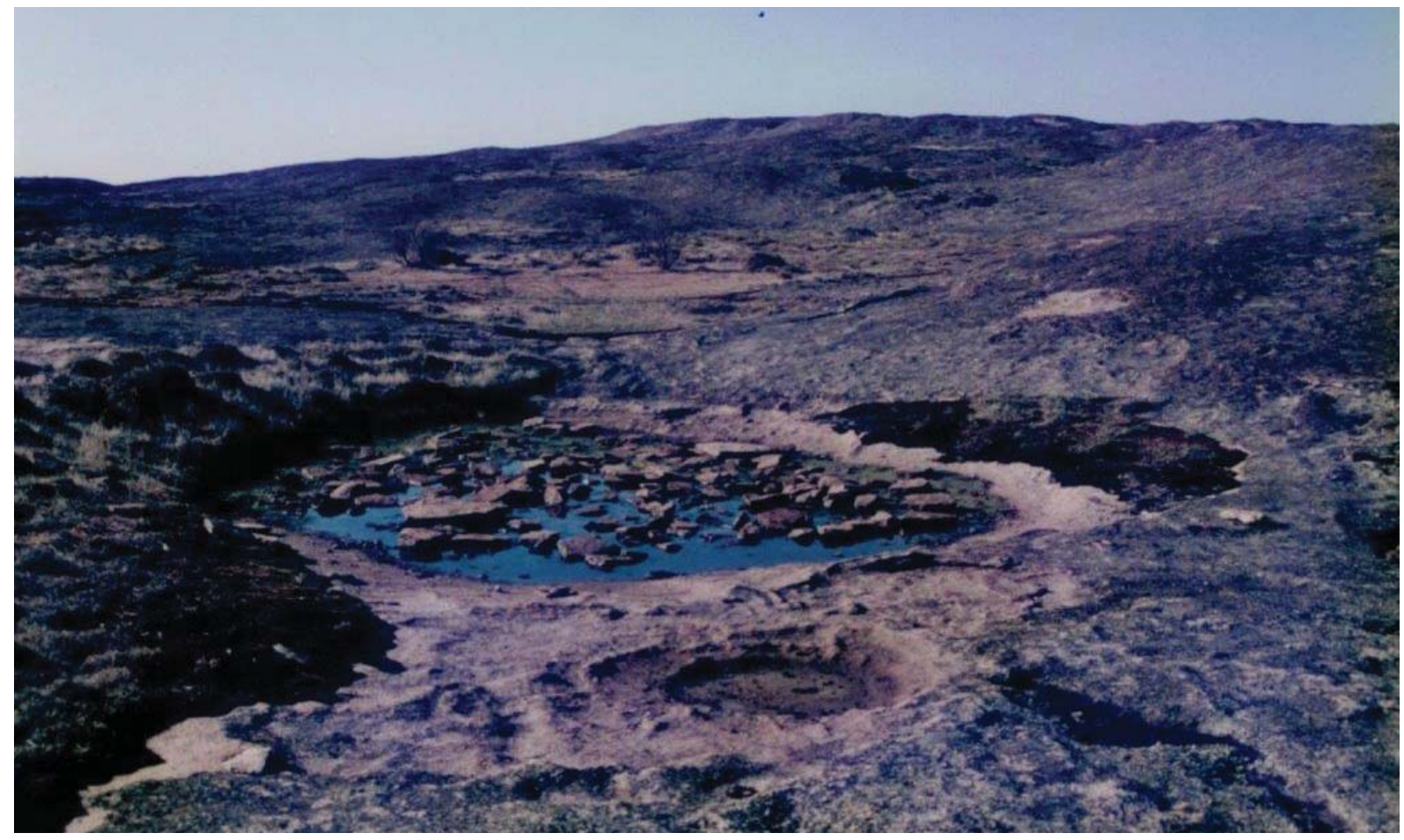

Fig. 7. Basin with double rim and, nearby, basin with rock fragments (remains of boulder?) eastern sector of Hyden Rock, southwest of Yilgarn Craton. 


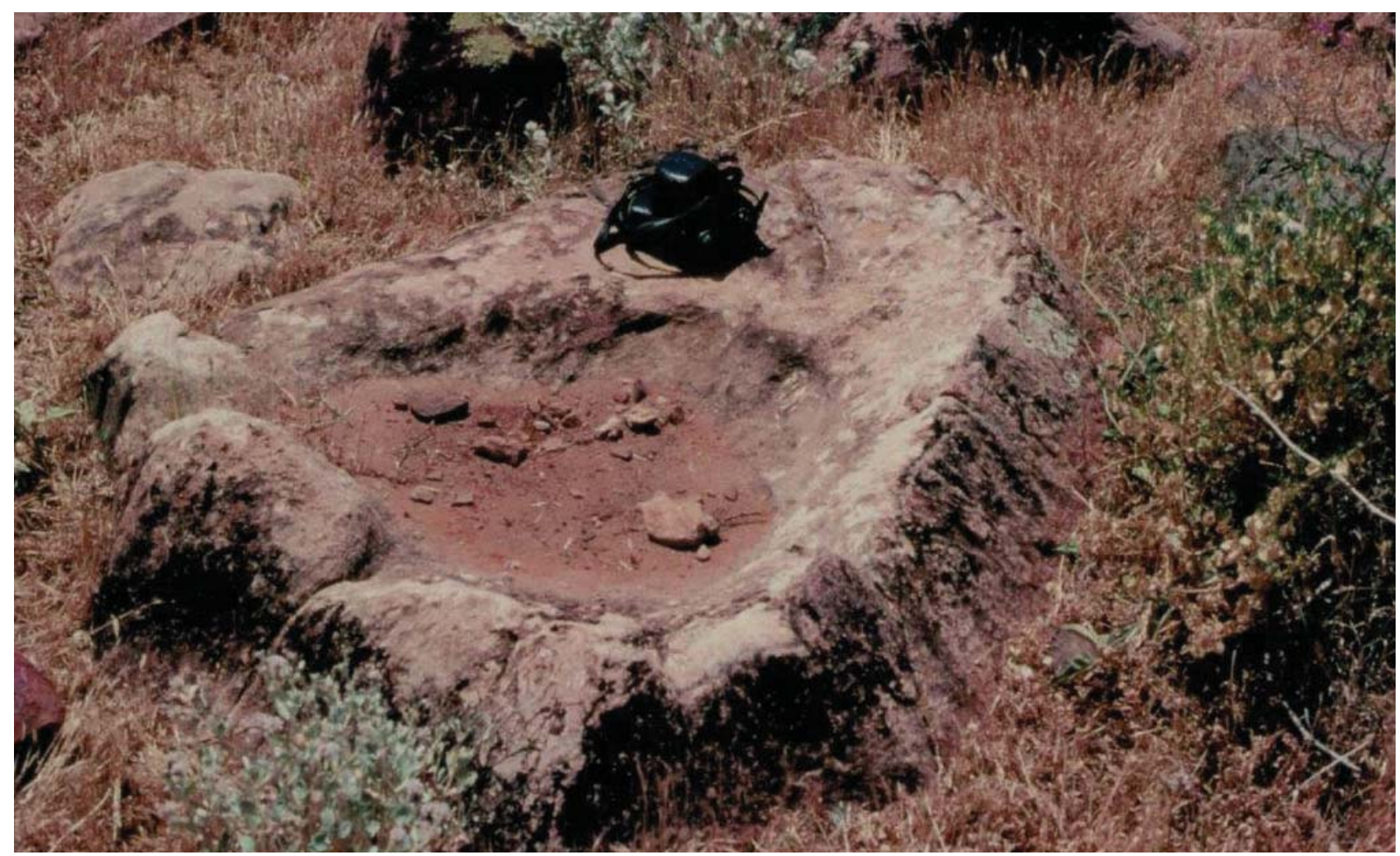

Fig. 8. Sandstone boulder with ferruginous (haematite/goethite skin and weathered hollow on crest, Aliena valley, southwest of Wilpena Pound, western piedmont of Flinders Ranges

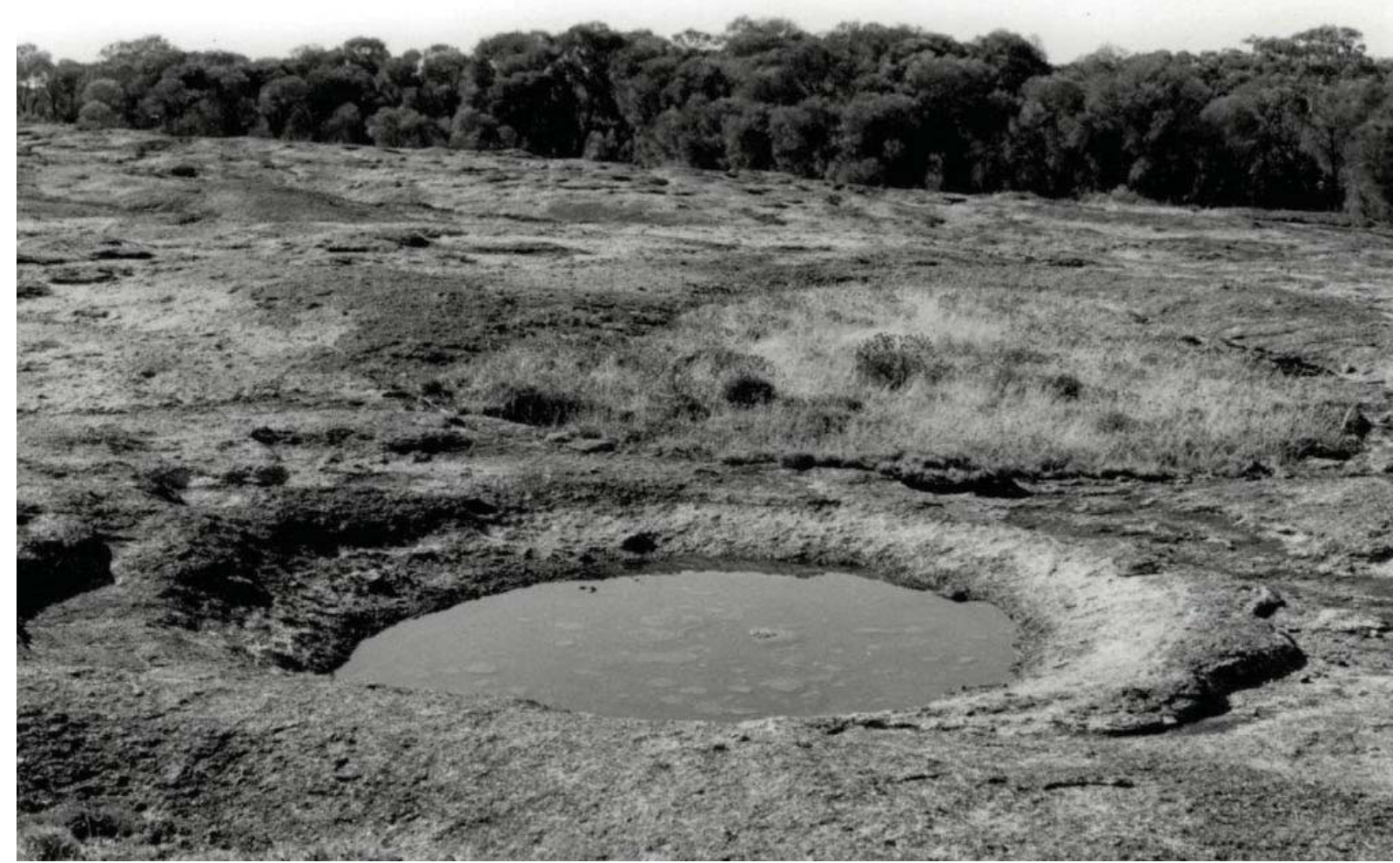

Fig. 9.Doughnut with opaline coated rim, Hyden Rock, southwestern Yilgarn Craton, Western Australia 


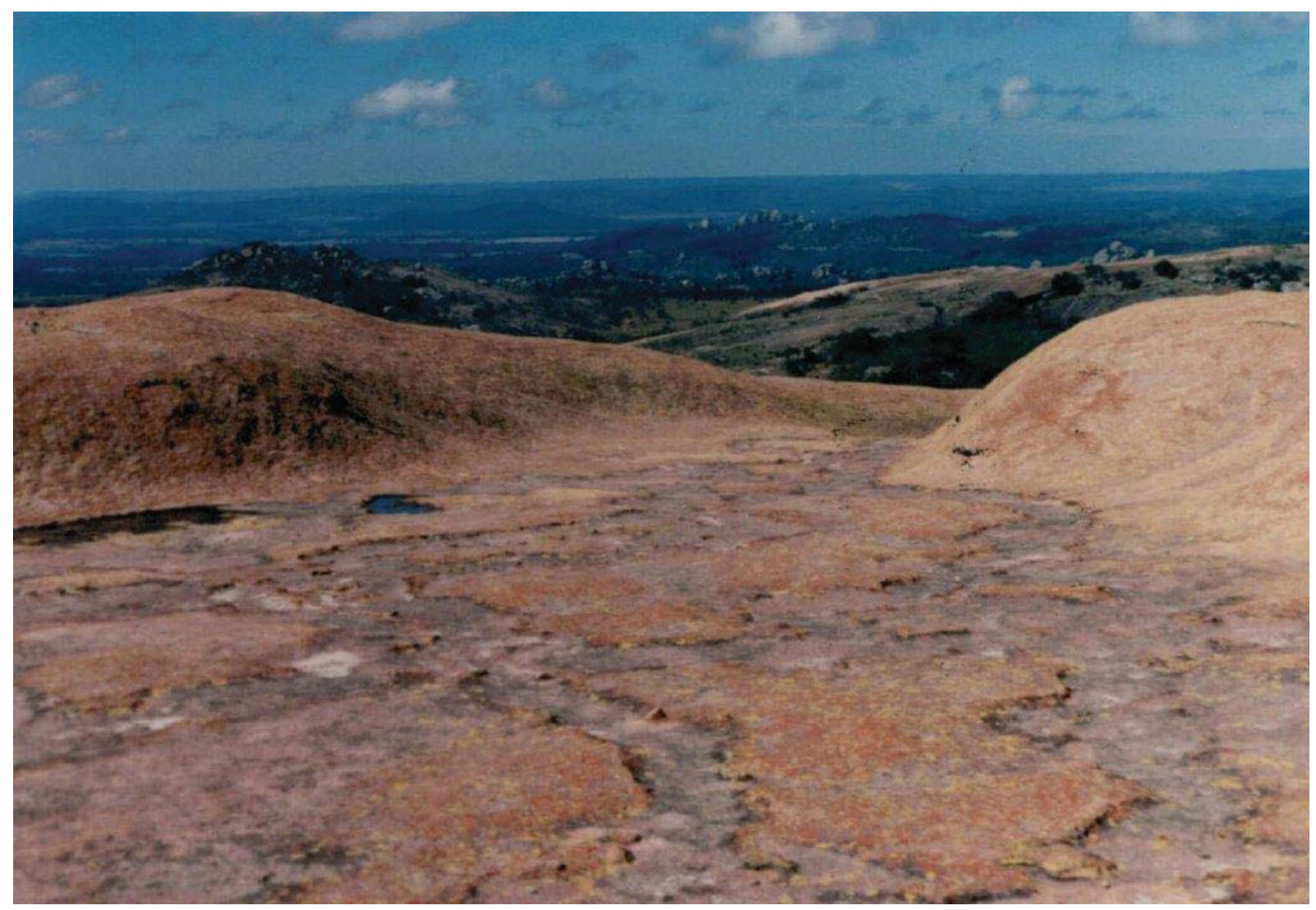

Fig. 10. Siliceous coating on valley floor, Domboshawa. 
a

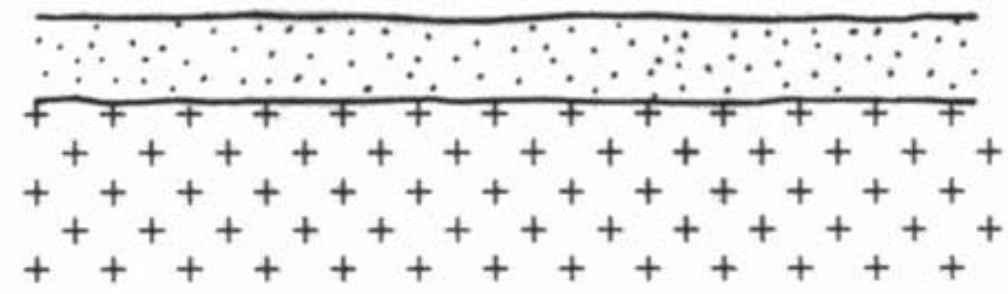

b

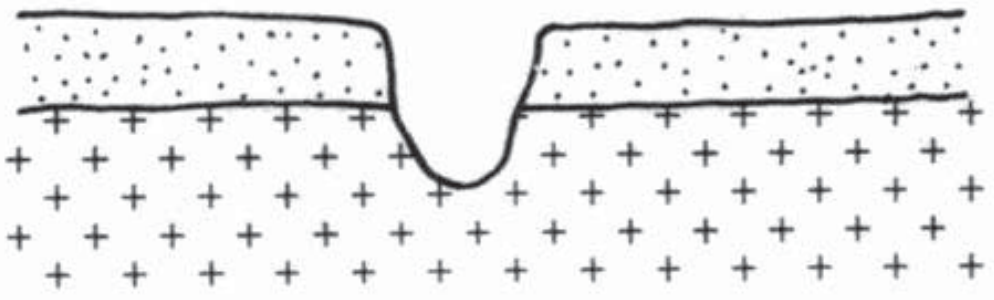

C

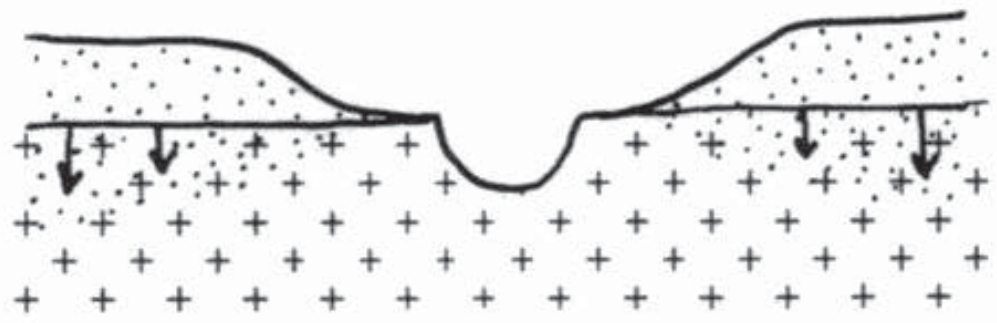

d

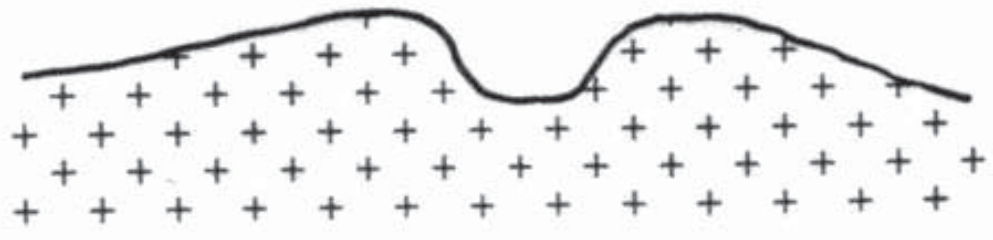

m

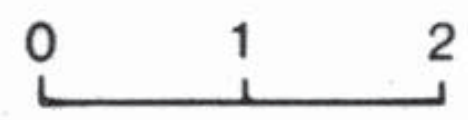

Fig. 11. Sections showing effect of drainage outlet on weathering of rock surface.

12.(a) Rims bordering fractures, King Rocks, some $30 \mathrm{~km}$ north east of Hyden southwestern Yilgarn Craton, Western Australia. (b) Incipient rock doughnuts formed around sau- cer shaped depressions and revealed on recently cleared granite platform, Kwaterski Rocks,20-25 km north of Minnipa. 


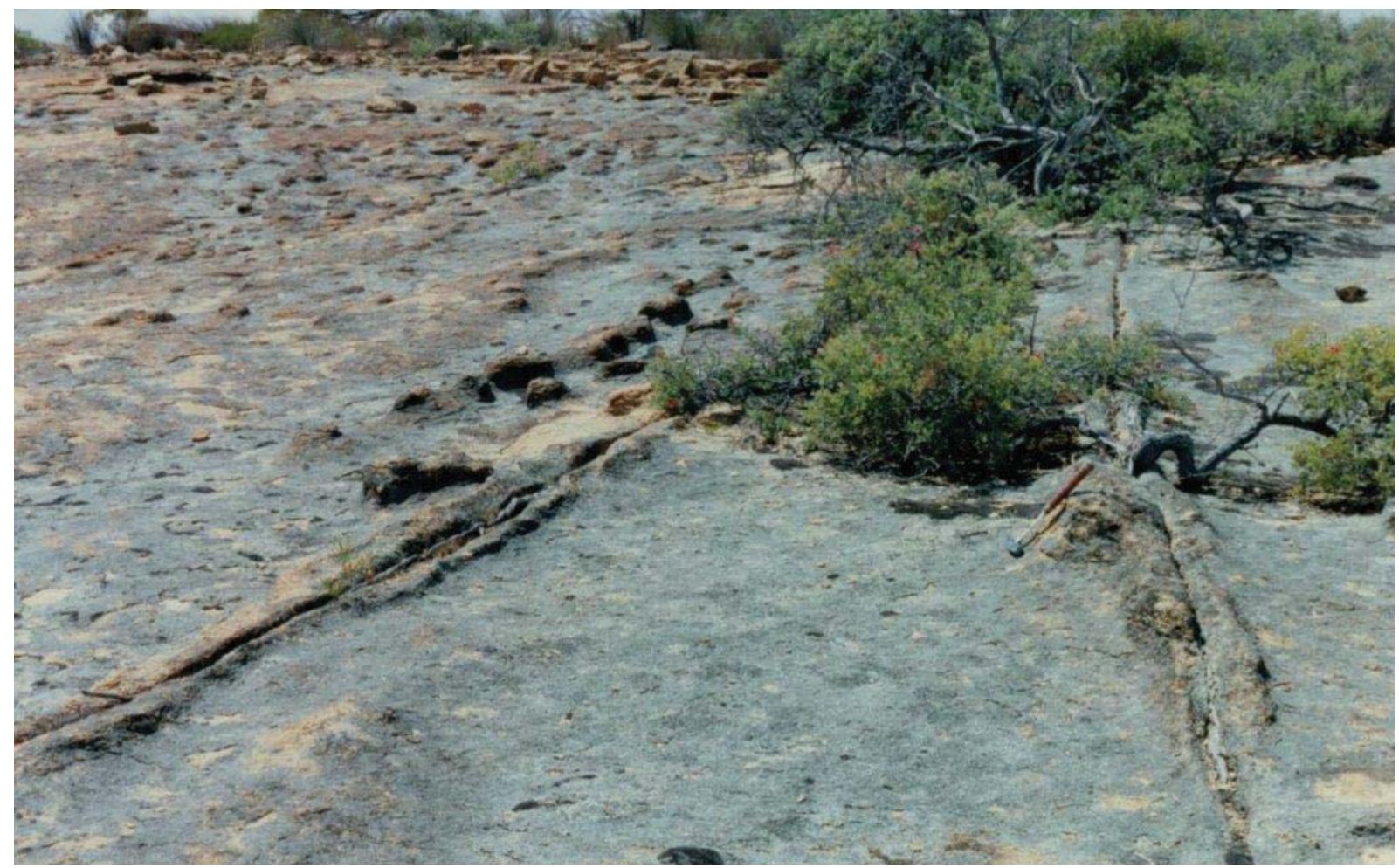

Fig. 12. a.

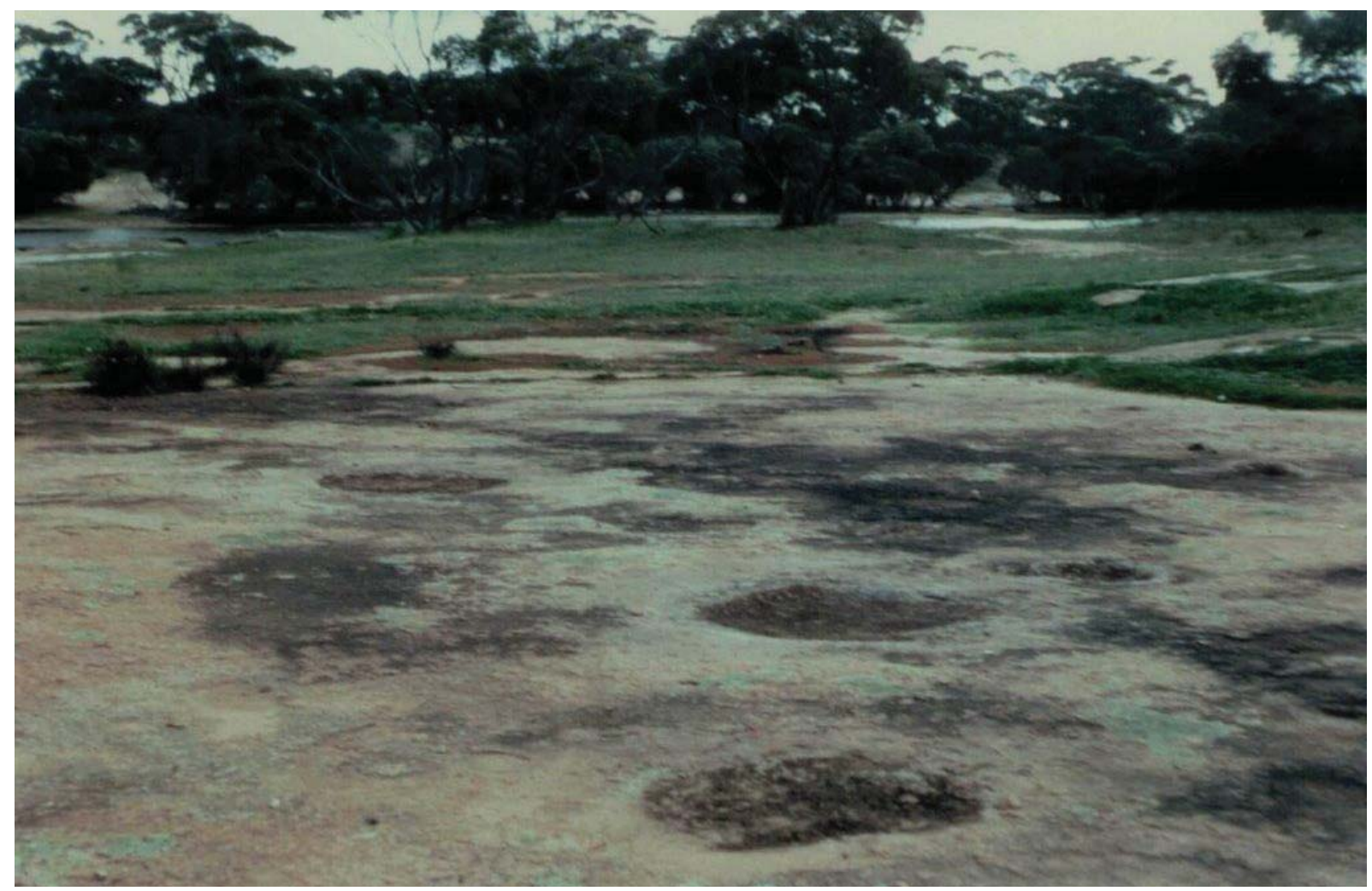

Fig. 12. b. 
Fig. 13.(a) Bevelled granite block with central depression, Richardson Rock $20 \mathrm{~km}$ SW of Coonalpyn, South East District of South Australia. (b) Basal pedestal exposed by to leve- ring boulder to one side and revealing rimmed shallow basin. Tcharkuldu Rock, $5 \mathrm{~km}$ east of Minnipa.

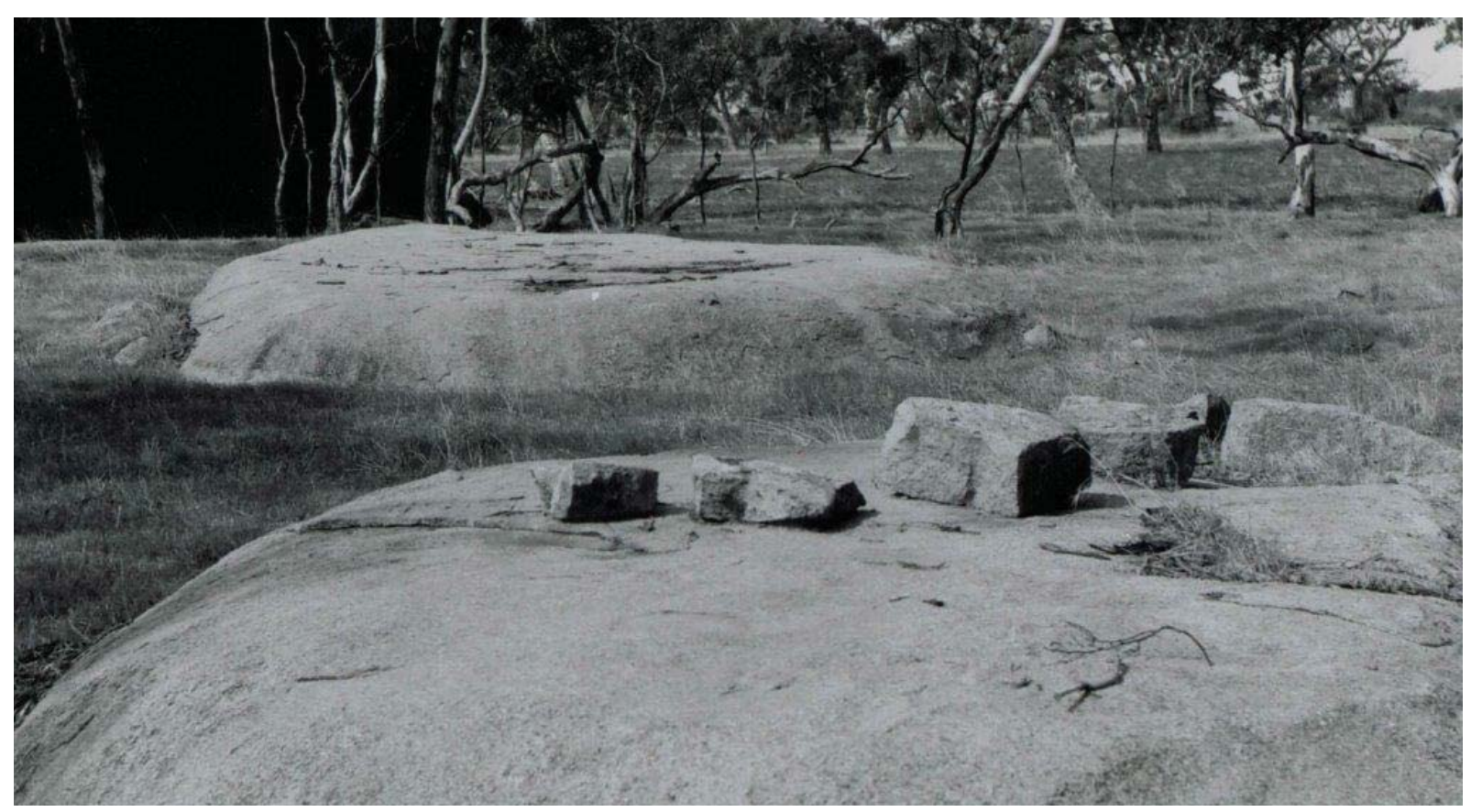

Fig. 13. a.

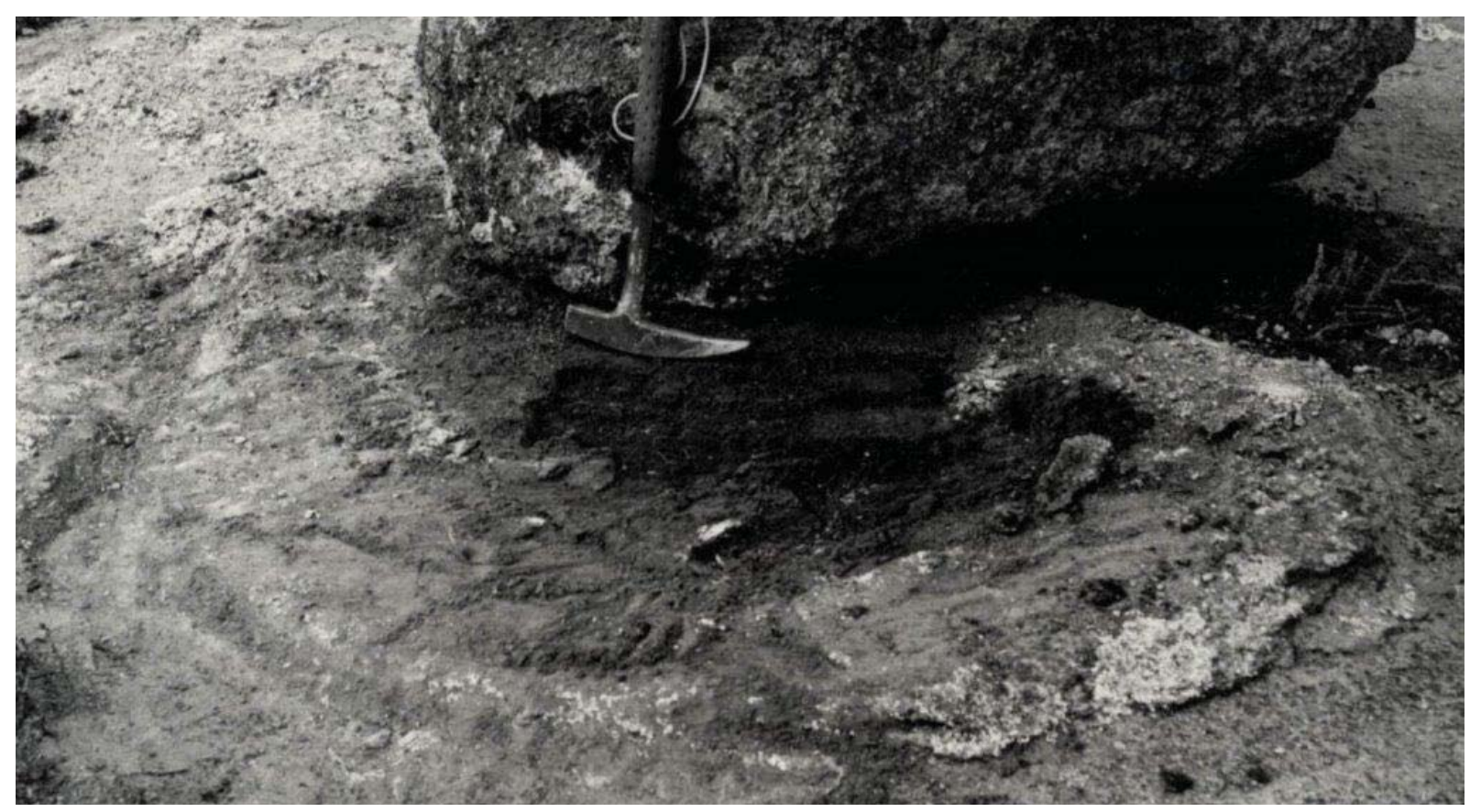

Fig. 13. b. 


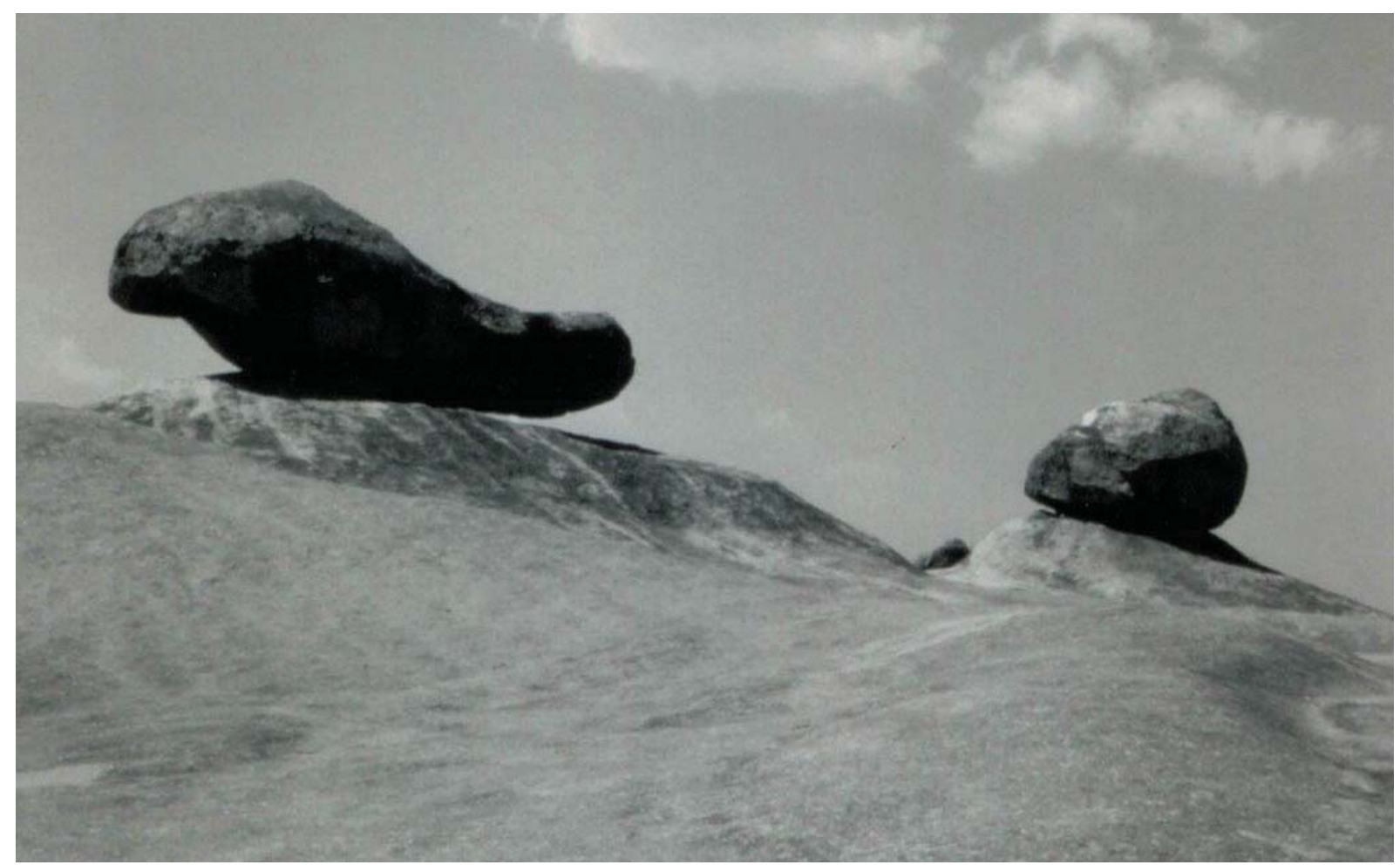

Fig. 14. a. Pedestal rocks, Domboshawa, northern Zimbabwe.

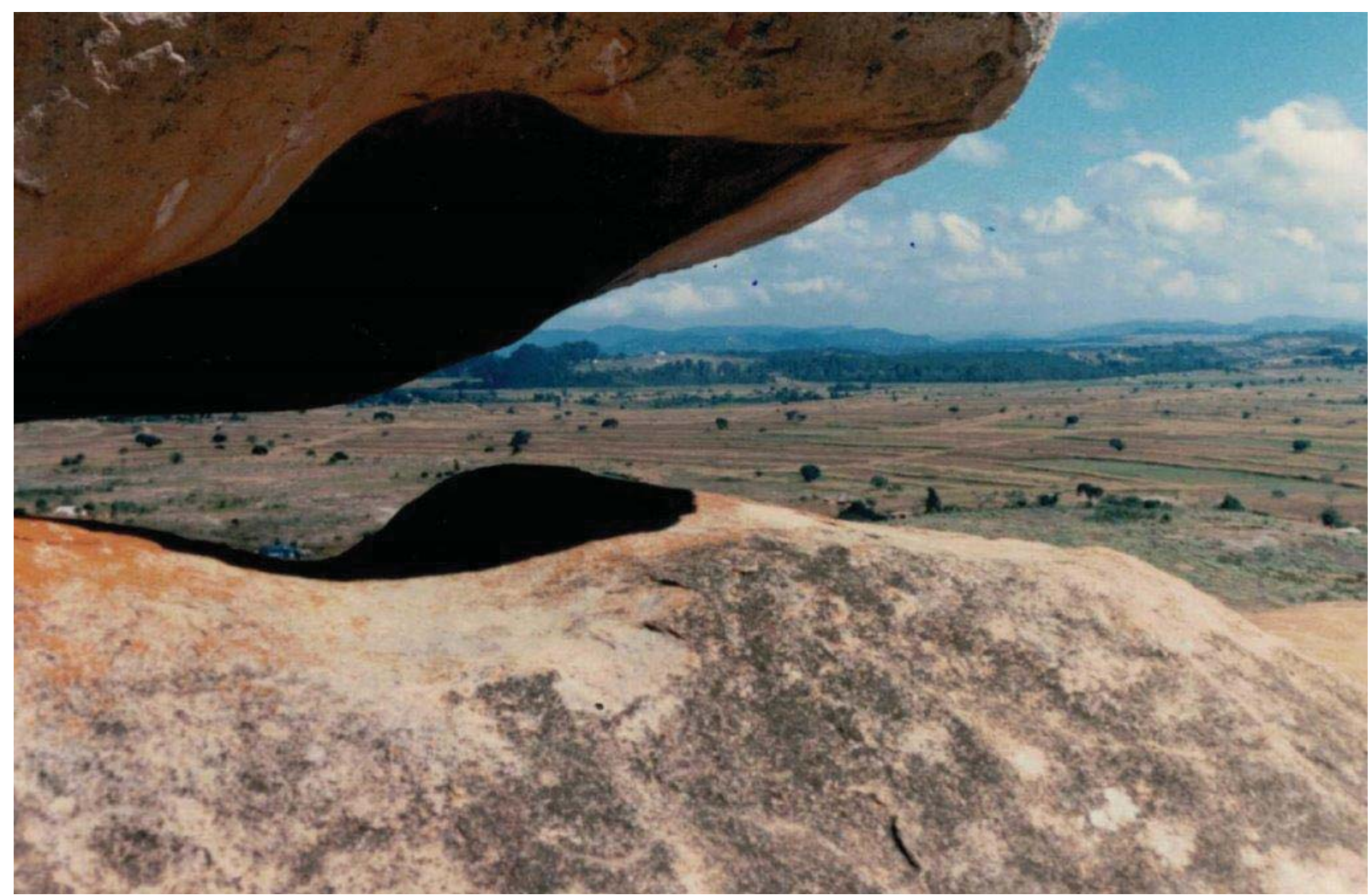

Fig. 14. b. Hollowed underside of boulder and matching basin, Domboshawa. 